\title{
Volatility basis-set approach simulation of organic aerosol formation in East Asia: implications for anthropogenic-biogenic interaction and controllable amounts
}

\author{
H. Matsui ${ }^{1}$, M. Koike ${ }^{2}$, Y. Kondo ${ }^{2}$, A. Takami ${ }^{3}$, J. D. Fast ${ }^{4}$, Y. Kanaya ${ }^{1}$, and M. Takigawa ${ }^{1}$ \\ ${ }^{1}$ Department of Environmental Geochemical Cycle Research, Japan Agency for Marine-Earth Science and Technology, \\ Kanagawa, Japan \\ ${ }^{2}$ Department of Earth and Planetary Science, Graduate School of Science, University of Tokyo, Tokyo, Japan \\ ${ }^{3}$ National Institute for Environmental Studies, Ibaraki, Japan \\ ${ }^{4}$ Pacific Northwest National Laboratory, Richland, Washington, USA
}

Correspondence to: H. Matsui (matsui@jamstec.go.jp)

Received: 14 February 2014 - Published in Atmos. Chem. Phys. Discuss.: 10 March 2014

Revised: 15 July 2014 - Accepted: 28 July 2014 - Published: 16 September 2014

\begin{abstract}
Organic aerosol (OA) simulations using the volatility basis-set approach were made for East Asia and its outflow region. Model simulations were evaluated through comparisons with OA measured by aerosol mass spectrometers in and around Tokyo (at Komaba and Kisai in summer 2003 and 2004) and over the outflow region in East Asia (at Fukue and Hedo in spring 2009). The simulations with aging processes of organic vapors reproduced the mass concentrations, temporal variations, and formation efficiencies of observed OA at all of the sites reasonably well. As OA mass was severely underestimated in the simulations without the aging processes, the oxidations of organic vapors are essential for reasonable OA simulations over East Asia. By considering the aging processes, simulated OA concentrations increased from 0.24 to $1.28 \mu \mathrm{g} \mathrm{m}^{-3}$ in the boundary layer over the whole of East Asia. OA formed from the interaction of anthropogenic and biogenic sources was also enhanced by the aging processes. The fraction of controllable OA was estimated to be $87 \%$ of total OA over the whole of East Asia, which indicated that most of the OA in our simulations were formed anthropogenically (from controllable combustion sources). A large portion of biogenic secondary OA ( $78 \%$ of biogenic secondary OA) was formed through the influence of anthropogenic sources. These fractions were higher than the fraction of anthropogenic emissions. An important reason for these higher controllable fractions was higher oxidant concentrations and the resulting faster oxidation rates of OA precursors by considering anthropogenic
\end{abstract}

sources. Both the amounts (from 0.18 to $1.12 \mu \mathrm{g} \mathrm{m}^{-3}$ ) and the fraction (from 75 to $87 \%$ ) of controllable OA were increased by aging processes of organic vapors over East Asia.

\section{Introduction}

Organic aerosol (OA) accounts for a significant mass fraction of submicron aerosols in the atmosphere (Kanakidou et al., 2005; Zhang et al., 2007) and influences the Earth's climate directly (by scattering/absorption of solar radiation) and indirectly (by modifying cloud microphysical properties) (Hallquist et al., 2009). OA is directly emitted from fossil fuel combustion, biomass burning, and other sources (primary organic aerosol, POA) or formed from the oxidation of thousands of volatile organic compounds (VOCs) in the atmosphere (secondary organic aerosol, SOA). Recent studies have shown that SOA accounts for a large fraction of OA globally (e.g., Kanakidou et al., 2005; Goldstein and Galbally, 2007; Zhang et al., 2007; de Gouw and Jimenez, 2009). However, as SOA formation processes are very complicated, estimates of the SOA burden in the atmosphere and its impact on climate and human health remain highly uncertain compared with those of other aerosols such as inorganic aerosol species (Hallquist et al., 2009). The current estimation of global SOA formation rate is about $30-450 \mathrm{Tg} \mathrm{yr}^{-1}$ 
(Hallquist et al., 2009; Heald et al., 2010; Spracklen et al., 2011).

In traditional OA models, the mass concentrations of SOA produced from individual parent VOCs (for example, isoprene and terpenes for biogenic VOCs, and benzene, toluene, and xylene for anthropogenic VOCs) are calculated by using two mass-based yield coefficients and two partitioning coefficients which are estimated by fitting of laboratory experimental results (two-product approach) (Odum et al., 1996, 1997). Various global- and regional-scale simulations have been made using these coefficients (e.g., Chung and Seinfeld, 2002; Tsigaridis and Kanakidou, 2003, 2007; Heald et al., 2005, 2008), but they have underestimated observed OA and/or SOA concentrations and formation rates in the atmosphere by roughly an order of magnitude, especially over urban regions (e.g., McKeen et al., 2007; Han et al., 2008; Matsui et al., 2009a).

More recently, a significant source of SOA was proposed by laboratory studies (e.g., Robinson et al., 2007), which found missing sources of semivolatile and intermediate volatility organic compounds (S / IVOCs) and the importance of chemical aging of S / IVOCs and VOCs in the atmosphere. Donahue et al. (2006) developed a new framework for OA modeling, the volatility basis set (VBS) approach. In the VBS, individual organic vapors are categorized to surrogate species with similar volatility, and their photochemical multigenerational oxidation and gas-particle partitioning processes are calculated. The VBS approach has recently been applied to global- and regional-scale simulations (e.g., Lane et al., 2008a, b; Farina et al., 2010; Pye and Seinfeld, 2010; Jathar et al., 2011). Improvements of the agreement between oxygenated OA (OOA, thought to be analogous to SOA) observed by aerosol mass spectrometers (AMS) and simulated SOA have been reported for the air over Mexico City (Hodzic et al., 2010; Tsimpidi et al., 2010, 2011; Shrivastava et al., 2011), the United States (Ahmadov et al., 2012), and Europe (Fountoukis et al., 2011; Athanasopoulou et al., 2013).

East and Southeast Asia is one of the largest sources of aerosols in the world (e.g., Dentener et al., 2006; Bond et al., 2013). Many studies have reported impacts of Asian aerosols on regional and hemispherical scales (e.g., Ramanathan et al., 2001; Carmichael et al., 2003; Adhikary et al., 2010; Matsui et al., 2011a, b, 2013a; Oshima et al., 2012, 2013). Several global and regional modeling studies have simulated and evaluated OA over East Asia (e.g., Heald et al., 2005, 2011; Han et al., 2008; Matsui et al., 2009a; Utembe et al., 2011; Mahmud and Barsanti, 2013). Most previous OA simulation studies have underestimated observed OA and SOA concentrations over the region. For example, Utembe et al. (2011) evaluated their global OA simulations over the outflow region in East Asia through the comparisons with OA measurements during the ACE-Asia campaign. While their simulations reproduced the vertical profile of observed OA mass concentrations, they underestimated absolute OA mass con- centrations by a factor of 5 . Matsui et al. (2009a) simulated OA over the urban area of Tokyo in July and August 2003. The simulations reproduced the absolute concentrations and their temporal variations of observed $\mathrm{NO}_{\mathrm{x}}$, ozone $\left(\mathrm{O}_{3}\right)$, VOCs, and inorganic aerosols reasonably well, but severely underestimated observed SOA (by a factor of 5) and OA concentrations (by a factor of 2).

Few studies have focused on OA concentrations and their spatial distributions over the whole of East and Southeast Asia and its outflow region (Han et al., 2008; Jiang et al., 2012). They also underestimated observed OA and/or SOA concentrations over China. As the VBS approach has a potential to explain realistic OA concentrations over East and Southeast Asia, the application and evaluation of the VBS approach to the Asian region is important to obtain a quantitative understanding of OA concentrations and their spatial distributions over this region.

The understanding on the interaction of anthropogenic and biogenic sources is also very limited over the Asian region. Anthropogenic sources may substantially influence biogenic SOA (BSOA) formation (e.g., Carlton et al., 2010; Hoyle et al., 2011; Spracklen et al., 2011). The formation of BSOA is enhanced by anthropogenic POA, $\mathrm{NO}_{\mathrm{x}}$, and VOCs because they increase the concentrations of precursor VOCs, the oxidation rates of VOCs, and the particle-to-gas partitioning ratios of organic compounds (e.g., Heald et al., 2008; Tsigaridis et al., 2006; Tsigaridis and Kanakidou, 2007). Carlton et al. (2010) estimated the effect of anthropogenic emissions on BSOA formation and demonstrated that more than $50 \%$ of the predicted BSOA concentrations were influenced by anthropogenic emissions in the eastern United States. Some global modeling studies have estimated much higher contributions from enhanced BSOA (Tsigaridis et al., 2006; Hoyle et al., 2009; Spracklen et al., 2011). As anthropogenic and biogenic emissions are both very large over East and Southeast Asia, the interaction of anthropogenic and biogenic sources and the resulting enhancement of BSOA are very important and should be examined for this region. These understandings would be useful for estimating the past, current, and future OA concentrations and their regional and hemispherical climatic impacts.

The objective of this study is to understand OA concentrations and their spatial distributions over East and Southeast Asia and its outflow region with the interaction of anthropogenic and biogenic sources. We simulate OA concentrations over East Asia and its outflow region by using a VBS model we have developed (Sect. 2), and evaluate the results through comparisons with AMS measurements conducted in and around Tokyo and over the outflow region in East Asia (Sects. 3 and 4). OA spatial distributions over East Asia are described with the importance of aging treatments in the VBS (Sect. 5.1.1). We also examine the interaction of anthropogenic and biogenic sources in OA formation processes, such as the enhancement of BSOA formation due to aging processes of anthropogenic S/IVOCs and VOCs 
(Sect. 5.1.3). Finally, we estimate the contribution of anthropogenically induced (controllable) OA over East Asia and the impact of aging treatments on it (Sect. 5.2). The abbreviations of organic vapors and aerosols used in this study are summarized in Table 1.

\section{Regional three-dimensional model}

\subsection{WRF-Chem model}

In this study, we use the Weather Research and ForecastingChemistry (WRF-Chem) model with the MOSAIC aerosol module (version 3.4) (Skamarock et al., 2008; Grell et al., 2005; Fast et al., 2006; Zaveri et al., 2008), which has been used in our previous studies (Matsui et al., 2009b, 2010, 2011c, 2013b, 2013c), with modifications of the schemes related to organic aerosol formation (see Sect. 2.2). The chemical processes considered in the original WRF-Chem model are emissions of gaseous and aerosol species, gasphase chemistry (Zaveri and Peters, 1999), new particle formation (Wexler et al., 1994), dynamical gas-particle partitioning (condensation/evaporation) (Zaveri et al., 2005a, b, 2008), Brownian coagulation (Jacobson et al., 1994), aerosol activation (Abdul-Razzak and Ghan, 2000), aqueous-phase chemistry for inorganic species (Fahey and Pandis, 2001), and dry and wet deposition (Easter et al., 2004). The mass (sulfate $\left(\mathrm{SO}_{4}\right)$, nitrate, ammonium, black carbon (BC), POA, dust, sodium, chloride, and aerosol water) and number concentrations of aerosols are explicitly calculated for the size range from $40 \mathrm{~nm}$ to $10 \mu \mathrm{m}$ in eight size bins. The meteorological and chemical process options adopted in this study are summarized in Table 2. More detailed descriptions of the WRF-Chem/MOSAIC model are given elsewhere (Fast et al., 2006).

\subsection{OA formation scheme (VBS)}

The WRF-Chem model was modified to consider OA formation processes using the VBS approach (Fig. 1). Table 3 shows the summary of the OA formation scheme developed in this study. Similar to previous studies (e.g., Lane et al., 2008a; Tsimpidi et al., 2010; Shrivastava et al., 2011), this study uses nine surrogate volatility species to represent $\mathrm{S} /$ IVOCs with effective saturation concentrations $\left(C^{*}\right.$, saturation concentrations at $300 \mathrm{~K}$ ) of $10^{-2}, 10^{-1}, 1,10,10^{2}$, $10^{3}, 10^{4}, 10^{5}$, and $10^{6} \mu \mathrm{g} \mathrm{m}^{-3}$. Gas-phase chemistry is represented by the SAPRC99 mechanism (Carter, 2000) with the formation of first-generation oxidized VOCs (OVOCs) from the nine lumped VOCs: alkanes (ALK4 and ALK5), olefins (OLE1 and OLE2), aromatics (ARO1 and ARO2), isoprene (ISOP), monoterpene (TERP), and sesquiterpene (SESQ). The mass yields of the OVOCs from each lumped VOC are calculated using the same $\mathrm{NO}_{\mathrm{x}}$-dependent fourproduct basis fit $\left(C^{*}\right.$ of $1,10,100$, and $\left.1000 \mu \mathrm{g} \mathrm{m}^{-3}\right)$ used by Tsimpidi et al. (2010). S/IVOCs and OVOCs are oxi- dized to the surrogate species with an order of magnitude lower $C^{*}$ by $\mathrm{OH}$ radical with an assumed rate constant of $1 \times 10^{-11} \mathrm{~cm}^{3}$ molecule ${ }^{-1} \mathrm{~s}^{-1}$ (Fig. 1). The increase in SOA mass due to the addition of an oxygen atom is taken into account, as described by Tsimpidi et al. (2010): $7.5 \%$ increase for the reduction of volatility by 1 order of magnitude. The enthalpy of vaporization is based on Tsimipidi et al. (2010) and Lane et al. (2008a): $64-112 \mathrm{~kJ} \mathrm{~mol}^{-1}$ for POA and $30 \mathrm{~kJ} \mathrm{~mol}^{-1}$ for SOA. Our scheme traces 53 surrogate vapor species ( 9 for primary S/IVOCs, 8 for oxygenated S/IVOCs, and 36 for OVOCs) and the corresponding 53 aerosol species for bulk aerosol mass concentrations. In this study, we define oxidized POA (OPOA) as OA from oxygenated S / IVOCs, anthropogenic SOA (ASOA) as OA from anthropogenic VOCs (ALK4, ALK5, OLE1, OLE2, ARO1, and $\mathrm{ARO} 2$ ), and biogenic SOA (BSOA) as OA from biogenic VOCs (ISOP, TERP, and SESQ) (Fig. 1).

The scheme assumes equilibrium between the vapor and particulate species. Bulk equilibrium gas-particle partitioning is calculated with an iteration scheme of Schell et al. (2001). The changes in size-resolved mass concentrations in the eight size bins are calculated based on Koo et al. (2003) with the Kelvin effect. The fraction of total flux of species $i$ between gas and aerosol phases that condenses onto or evaporates from aerosol size bin $k\left(f_{i, k}\right)$ is given by

$$
f_{i, k}=\frac{2 \pi N_{k} d_{k} D_{i} F\left(C_{i}-C_{i}^{\mathrm{eq}} \eta\right)}{\sum_{k} 2 \pi N_{k} d_{k} D_{i} F\left(C_{i}-C_{i}^{\mathrm{eq}} \eta\right)},
$$

where $N_{k}$ is the number concentrations in bin $k ; d_{k}$ is the mean diameter of bin $k ; D_{i}, C_{i}$, and $C_{i}^{\mathrm{eq}}$ are the diffusivity, bulk gas-phase concentration, and equilibrium concentration at the particle surface of species $i$, respectively; $F$ is the correction for the non-continuum effects which depends on the Knudsen number and the accommodation coefficient (we assume a value of 0.1 , which has been used in previous studies; Zhang et al., 2004; Zaveri et al., 2008); and $\eta$ is the Kelvin effect correction. In our scheme, Eq. (1) is calculated for individual VBS species (53 species), but all of the size-resolved information is not directly used to calculate the three-dimensional transport processes to reduce the computational cost. Only total OA (sum of all VBS species) is transported with the size-resolved information, and individual VBS species are transported with the information of bulk mass concentrations only (not size-resolved, and we assume that all VBS species have the same size distribution). This treatment can reduce the number of transport variables (therefore computational cost) by a factor of 4 compared with the size-resolved treatment for all VBS species and by a factor of 3 compared with the four-bin scheme presented in Shrivastava et al. (2011), which was implemented in the original WRF-Chem model (Table 3). Therefore, the scheme developed in this study is a detailed (nine species), size-resolved (for total OA), and computationally efficient VBS scheme. 
Table 1. Abbreviations for organic vapors and aerosols used in this study.

\begin{tabular}{|c|c|c|}
\hline Abbreviation & Definition & Explanation \\
\hline $\mathrm{OA}$ & Organic aerosol & - \\
\hline POA & Primary OA & $\begin{array}{l}\text { Primary emission or formed from S / IVOCs by } \\
\text { equilibrium (without oxidation) }\end{array}$ \\
\hline SOA & Secondary OA & Sum of OPOA, BSOA, and ASOA \\
\hline VOCs & Volatile organic compounds & Primary emission \\
\hline S / IVOCs & $\begin{array}{l}\text { Semivolatile and intermediate } \\
\text { volatility organic compounds }\end{array}$ & $\begin{array}{l}\text { Primary emission (primary S / IVOCs) or sec- } \\
\text { ondary production through the oxidation of pri- } \\
\text { mary S / IVOCs (oxygenated S / IVOCs) }\end{array}$ \\
\hline OVOCs & $\begin{array}{l}\text { Oxygenated volatile organic } \\
\text { compounds }\end{array}$ & Oxidation products of VOCs \\
\hline $\mathrm{HOA}$ & Hydrocarbon-like OA & Obtained by AMS \\
\hline OOA & Oxygenated OA & Obtained by AMS \\
\hline OPOA & Oxygenated POA & OA formed from oxygenated S / IVOCs \\
\hline BSOA & Biogenic SOA & OA formed from biogenic OVOCs \\
\hline ASOA & Anthropogenic SOA & $\begin{array}{l}\text { OA formed from anthropogenic OVOCs } \\
\text { (including biomass burning sources) }\end{array}$ \\
\hline
\end{tabular}

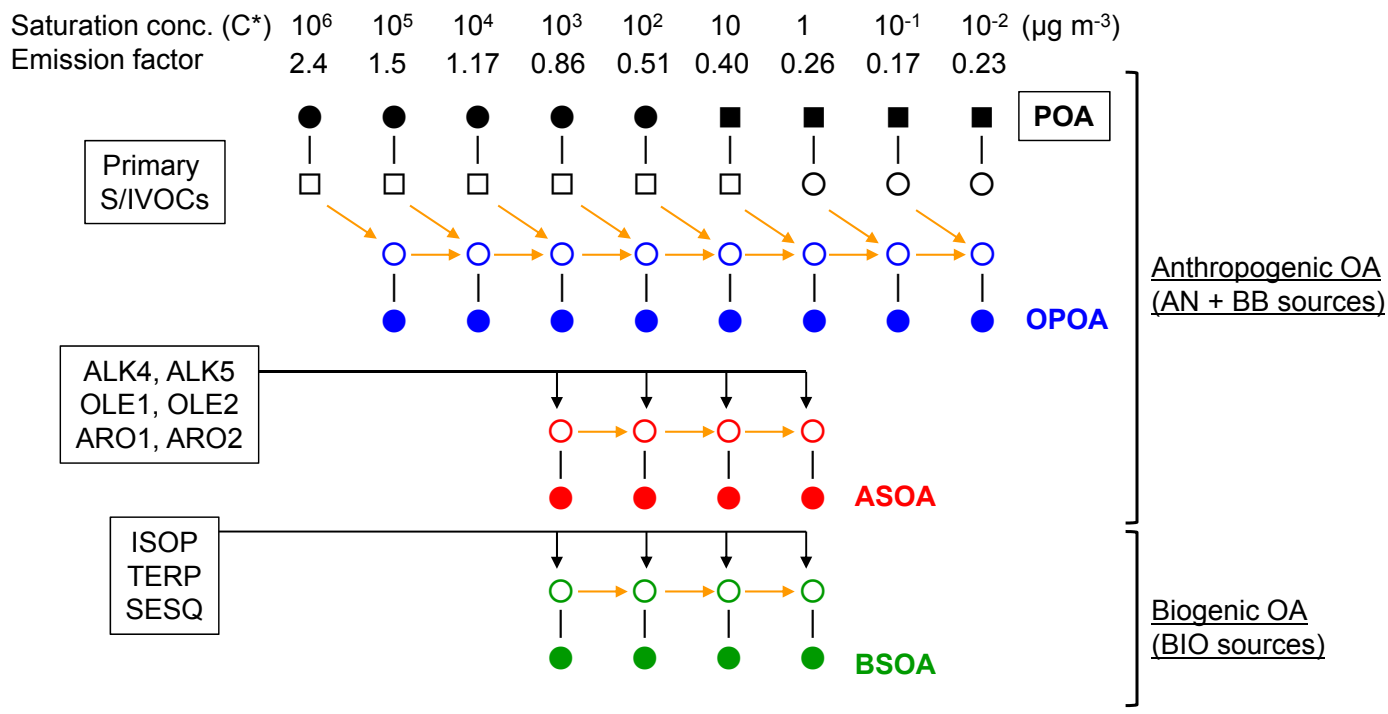

Figure 1. Summary of the volatility basis-set approach used in this study. Circles and squares show individual gas-phase (open) and aerosolphase (closed) surrogate species. Squares denote primary emission species. AN, BB, and BIO denote anthropogenic, biomass burning, and biogenic sources, respectively. The oxidation processes shown by the black arrows are calculated using the coefficients given by Tsimipidi et al. (2010). The oxidation processes shown by the orange arrows are calculated by assuming $\mathrm{OH}$ oxidation with a rate coefficient of $1 \times 10^{-11} \mathrm{~cm}^{3}$ molecule $\mathrm{s}^{-1}$.

In WRF-Chem, interstitial (aerosol-phase) and in-cloud (cloud-phase) aerosols are treated separately for all aerosol species (five inorganic species, BC, OA, and dust) and size bins to calculate in-cloud aerosol formation, regeneration, and wet removal processes. Therefore, OA size distribution is calculated separately for the aerosol phase and cloud phase in our model. The model considers the increase in total OA (sum of all VBS species) through aerosol regeneration after cloud evaporation. As the information of each VBS species is not calculated for in-cloud aerosols in our model, the chemical compositions (mass fraction of each VBS species) of re- generated $\mathrm{OA}$ are assumed to equal those of interstitial OA at the same three-dimensional grid cell.

The emission factors of S / IVOCs and POA were assumed based on Shrivastava et al. (2011). In this study, we applied the factors for anthropogenic sources (Table 2 of Shrivastava et al., 2011) to all the emission sources. The sum of all S / IVOCs and POA emissions is 7.5 times the traditional POA emissions (Fig. 1), which are based on the rough estimate of the SVOC/POA ratio of 3 and the IVOC/SVOC ratio of 1.5 (or the IVOC / POA ratio of 4.5) in previous studies (Tsimpidi et al., 2010; Shrivastava et al., 2011). To ensure 
Table 2. Meteorological and chemical process options used in this study.

\begin{tabular}{ll}
\hline Atmospheric process & Model option \\
\hline Longwave radiation & RRTM \\
Shortwave radiation & Goddard \\
Surface layer & Monin-Obukhov \\
Land surface & Noah \\
Boundary layer & YSU \\
Cumulus clouds & Kain-Fritsch \\
Cloud microphysics & Morrison, 2-moment \\
Gas-phase chemistry & SAPRC99 \\
Aerosol nucleation & Binary nucleation \\
Aerosol condensation & MOSAIC \\
Aerosol coagulation & COAGSOLV \\
Aqueous-phase chemistry & Fahey and Pandis (2001) \\
Photolysis & Fast-J \\
\hline
\end{tabular}

consistent aerosol number concentrations between the traditional OA emissions and the S/IVOCs/POA emissions, we assume particulate emissions (POA) for $C^{*}$ ranging from $10^{-2}$ to $1 \mu \mathrm{g} \mathrm{m}^{-3}$, gas-phase emissions (S/IVOCs) for $C^{*}$ ranging from $10^{6}$ to $10^{2} \mu \mathrm{g} \mathrm{m}^{-3}$, and a mixture of gas-phase and particulate emissions for $C^{*}$ of $10 \mu \mathrm{g} \mathrm{m}^{-3}$ (Fig. 1).

Dry deposition of organic vapors (S / IVOCs and OVOCs) is calculated by the scheme of Wesely (1989), which is used in the original WRF-Chem/MOSAIC model. In this study, the dry deposition velocity of $\mathrm{HNO}_{3}$ is assumed for all of the organic vapors, which is consistent with Ahmadov et al. (2012). Dry deposition of OA is calculated for each size bin with the scheme used in the original WRF-Chem model (Binkowski and Shankar, 1995; Easter et al., 2004). In-cloud scavenging of organic vapors (S / IVOCs and OVOCs) is calculated by assuming an aqueous-phase fraction of unity (all organic vapors are soluble). Below-cloud scavenging of organic vapors is calculated by assuming the mass transfer rate of $\mathrm{HNO}_{3}$ to rain given in Levine and Schwarz (1982). Incloud and below-cloud scavenging of OA are calculated for each size bin as calculated in the original WRF-Chem model (Easter et al., 2004). A hygroscopicity value $(\kappa)$ of 0.14 , which is the value used in the original WRF-Chem for POA, is assumed for all OA species used in the VBS.

In our VBS model, oxidation processes are considered only for gaseous species, namely homogenous aging by $\mathrm{OH}$ radicals. Our model does not consider other processes, such as aqueous-phase reactions (e.g., Ervens et al., 2011; Liu et al., 2012), heterogeneous oxidation (e.g., George et al., 2007, 2008), oligomerization (e.g., Kalberer et al., 2004; Iinuma et al., 2004), and fragmentation (e.g., Jimenez et al., 2009; Kroll et al., 2009; Murphy et al., 2012). These processes could be important because they alter the volatility and oxidation state (i.e., an atomic $\mathrm{O} / \mathrm{C}$ ratio) of organic vapors and OA, which leads to changes in OA concentrations. However, these processes currently have large uncertainties re- garding their reaction rates and products (Hallquist et al., 2009). Some recent studies have developed two-dimensional VBS schemes (2-D VBS) in which the volatility and oxidation state were calculated by considering functionalization and fragmentation (e.g., Jimenez et al., 2009; Donahue et al., 2011; Murphy et al., 2011, 2012; Shrivastava et al., 2013). In Murphy et al. (2012), heterogeneous oxidation and aqueous-phase chemistry processes were also taken into account. They applied their one-dimensional (column) chemical transport model to Europe and showed that the simple one-dimensional (volatility only) VBS (1-D VBS) scheme reproduced observed $\mathrm{OA}$ mass concentrations and $\mathrm{O} / \mathrm{C}$ ratios reasonably well and that the performance of the 1-D VBS scheme was not worse than that of their more complex 2-D VBS schemes, likely due to the uncertainties in understanding of SOA evolution in the atmosphere. Considering these uncertainties and computational costs of complex 2-D VBS schemes, we use a simpler 1-D VBS scheme in this study.

\subsection{Uncertainties in the treatment of the VBS model}

To understand the uncertainties of the simplicity in our VBS model, we conducted a sensitivity simulation without the simplicity. In this simulation, OA size distribution is calculated for each VBS species (53 species $\times 8$ size bins). Aerosol-phase and cloud-phase aerosols and their size distributions are calculated separately for each VBS species. From the comparison between the sensitivity simulation including the full representations of OA species and the base case simulation, the uncertainties in the estimation of SOA mass concentrations in the base simulation were estimated to be about $20 \%$ (as a total effect of OA formation, activation, and removal processes). The correlation coefficient $\left(R^{2}\right)$ of SOA spatial distribution (at about $1 \mathrm{~km}$ ) between the two simulations was 0.96 , suggesting that the performance of the OA distributions is sufficient in the base case simulation.

Our VBS scheme includes large uncertainties in the treatments of aging parameters, emission factors, and dry and wet deposition of organic vapors, which could change simulated OA concentrations considerably. In this study, the sensitivity of aging coefficients is examined in Sects. 4.2 and 5.1.2. The uncertainties in the emission factors and the treatments of dry and wet deposition for organic vapors used in the VBS scheme are briefly described here. The S/IVOCsto-POA emission ratio of 7.5 that was used in this study is a highly uncertain parameter. A sensitivity simulation with an increase in SVOC ( $C^{*}$ ranging from $10^{3}$ to $10^{-2} \mu \mathrm{g} \mathrm{m}^{-3}$ ) emissions by a factor of 2 enhanced total OA and SOA concentrations by 25 and $45 \%$, respectively, in our application over East Asia (period- and domain-averaged values at an altitude of about $1 \mathrm{~km})$. Another sensitivity simulation with an increase in IVOC $\left(C^{*}\right.$ ranging from $10^{6}$ to $\left.10^{4} \mu \mathrm{g} \mathrm{m}^{-3}\right)$ emissions by a factor of 2 enhanced total OA and SOA concentrations by 20 and $15 \%$, respectively. These results suggest that OA concentrations are moderately sensitive to the treatment 
Table 3. Summary of the VBS schemes developed in this study and original WRF-Chem/MOSAIC model.

\begin{tabular}{|c|c|c|}
\hline Item/process & This study & Shrivastava et al. (2011) \\
\hline $\begin{array}{l}\text { Gas-phase } \\
\text { chemistry }\end{array}$ & SAPRC99 & SAPRC99 \\
\hline \multirow{3}{*}{$\begin{array}{l}\text { VBS volatility } \\
\text { species }\end{array}$} & 9 for POA and primary S / IVOCs & 9 for POA and primary S / IVOCs \\
\hline & 8 for OPOA and oxygenated S / IVOCs & 8 for OPOA and oxygenated S / IVOCs \\
\hline & 4 for ASOA, BSOA, and OVOCs & 4 for ASOA, BSOA, and OVOCs \\
\hline Oxidation species & VOCs, S / IVOCs, and OVOCs & VOCs and S / IVOCs \\
\hline OVOCs formation & $\begin{array}{l}\mathrm{NO}_{\mathrm{x}} \text {-dependent 4-product fit } \\
\text { (Tsimpidi et al., 2010) }\end{array}$ & $\begin{array}{l}\mathrm{NO}_{\mathrm{x}} \text {-dependent 4-product fit } \\
\text { (Tsimpidi et al., 2010) }\end{array}$ \\
\hline $\begin{array}{l}\text { Gas-particle } \\
\text { partitioning }\end{array}$ & $\begin{array}{l}\text { Bulk equilibrium } \\
\text { (Schell et al., 2001) }\end{array}$ & $\begin{array}{l}\text { Bulk equilibrium } \\
\text { (Donahue et al., 2006) }\end{array}$ \\
\hline $\begin{array}{l}\text { OA distribution to } \\
\text { each size bin }\end{array}$ & Koo et al. (2003) & Koo et al. (2003) \\
\hline $\begin{array}{l}\text { Number of size } \\
\text { bins }\end{array}$ & $8(40-10000 \mathrm{~nm})$ & $4(40-10000 \mathrm{~nm})$ \\
\hline Number of & 122 & 380 \\
\hline variables in & Gas phase: 53 & Gas phase: 76 \\
\hline VBS & Bulk aerosol: 53 & Size-resolved aerosol: 304 \\
\hline & $\begin{array}{l}\text { Size-resolved aerosol: } 16 \\
\text { (interstitial aerosol, in-cloud aerosol) }\end{array}$ & \\
\hline Dry deposition & On & On \\
\hline Aerosol activation & On & Off \\
\hline Wet deposition & On & Off \\
\hline
\end{tabular}

of S/IVOC emissions over East Asia. OA concentrations are sensitive to the dry deposition treatment of organic vapors because a factor of 2 different velocities for S/IVOCs and OVOCs lead to an increase/decrease in OA concentrations by about $50 \%$ in our application over East Asia. OA concentrations are also moderately sensitive to the wet deposition treatment of S / IVOCs and OVOCs. OA concentrations were increased by $25 \%$ in the simulation without wet deposition of S / IVOCs and OVOCs.

\section{Measurements and simulation setups}

In this study, we simulate OA formation both in and around Tokyo urban area (Sect. 3.1) and over East Asia (Sect. 3.2). The purpose of the simulation in and around Tokyo is to validate the VBS scheme over the region where meteorological fields, emissions, and the concentrations of precursor gaseous species are relatively well known (compared with over the Asian region). We used observed data during the Integrated Measurement Program for Aerosol and oxidant Chemistry in Tokyo (IMPACT) campaign (Takegawa et al., 2006a, b; Kondo et al., 2006, 2007, 2008, 2010). OA mass concentrations observed with an Aerodyne AMS and gaseous species such as $\mathrm{O}_{3}, \mathrm{OH}$, and VOCs are available for the campaign period. These data can be used to validate the simulations and constrain the parameters related to OA formation such as precursor VOCs. The simulation over Asia is conducted to understand the behavior of OA over all of East and Southeast Asia and its outflow region, though there are uncertainties in emissions and limitations of validations especially for precursor gases. OA mass concentrations (Aerodyne AMS) at two sites in Japan were used to evaluate the simulations over the outflow regions from the Asian continent.

\subsection{Simulation in and around Tokyo (summer 2003 and 2004)}

We used OA mass concentrations observed by an Aerodyne AMS and gaseous species of $\mathrm{O}_{3}$ and VOCs at an urban area, Komaba $\left(35.66^{\circ} \mathrm{N}, 139.67^{\circ} \mathrm{E}\right)$, Tokyo, in July and August 2003 during the IMPACT-2 campaign and at a suburban site, Kisai $\left(36.08^{\circ} \mathrm{N}, 139.55^{\circ} \mathrm{E}\right)$, Saitama, in July and August 2004 during the IMPACT-L campaign (Fig. 2a). Details of the measurements are given elsewhere (Takegawa et al., 2005, 2006a, b; Kondo et al., 2006, 2007, 2008, 2010; Shirai et al., 2007; Kanaya et al., 2007).

The oxygenated and hydrocarbon-like OA concentrations (OOA and HOA) were estimated by least-squares fits to the time series of $\mathrm{OA}$ using a linear combination of the time series of AMS-derived signals at the mass-to-charge $(\mathrm{m} / \mathrm{z})$ ratios of 44 and 57 (Zhang et al., 2005). Though there are some uncertainties in this method, the OOA/HOA concentrations derived from this method can be used as a proxy for SOA/POA concentrations because SOA and POA concentrations, which were estimated from the correlation of total OA with $\mathrm{CO}$, correlated well with $\mathrm{HOA}$ and OOA, with 
(a)

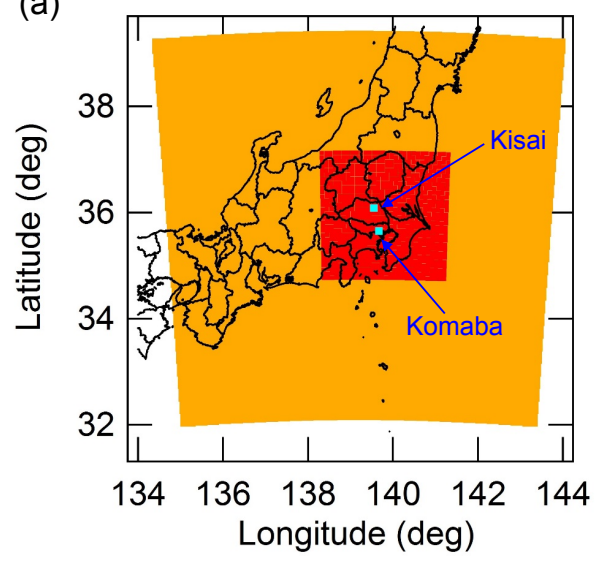

(b)

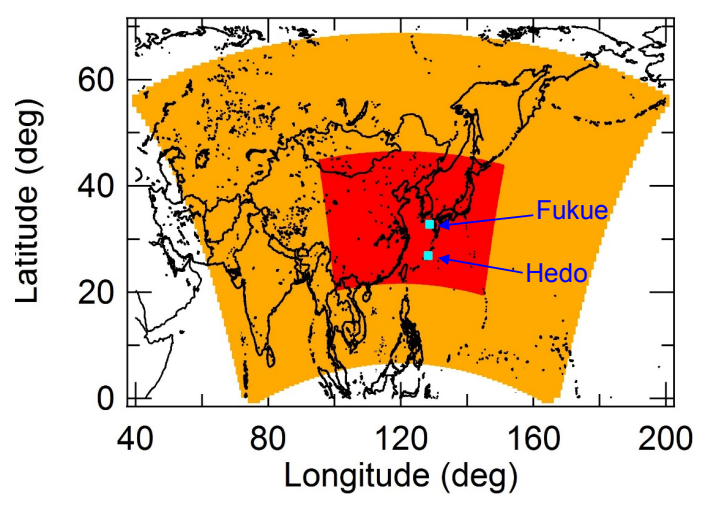

Figure 2. Simulation domains (a) in and around Tokyo during the IMPACT campaign and (b) over East Asia during the A-FORCE campaign. (a) Simulations were conducted for 17 July to 15 August 2003 (IMPACT-2) and for 23 July to 15 August 2004 (IMPACT-L) with horizontal resolutions of $27 \mathrm{~km}$ (outer domain, orange) and $9 \mathrm{~km}$ (inner domain, red). Light-blue squares show the locations of the measurement stations at Komaba $\left(35.66^{\circ} \mathrm{N}, 139.67^{\circ} \mathrm{E}\right)$ and Kisai $\left(36.08^{\circ} \mathrm{N}, 139.55^{\circ} \mathrm{E}\right)$. (b) Simulations were conducted for $21 \mathrm{March}$ to 26 April 2009 with horizontal resolutions of $180 \mathrm{~km}$ (outer domain, orange) and $60 \mathrm{~km}$ (inner domain, red). Light-blue squares show the locations of the measurement stations at Fukue $\left(32.75^{\circ} \mathrm{N}, 128.68^{\circ} \mathrm{E}\right)$ and Kisai $\left(26.87^{\circ} \mathrm{N}, 128.25^{\circ} \mathrm{E}\right)$.

slopes of $0.88-1.36\left(R^{2}\right.$ of $\left.0.76-0.85\right)$ and $0.97-1.41\left(R^{2}\right.$ of 0.65-0.85), respectively, during the IMPACT campaign (Takegawa et al., 2006a, b; Kondo et al., 2007). We used observed HOA concentrations to constrain POA emissions and to simulate realistic POA concentrations by the model (see below). Observed OOA is used to validate simulated SOA (Sect. 4.1).

For the simulations in and around Tokyo, the horizontal grid spacings in the model domain are $27 \mathrm{~km}$ (outer domain) and $9 \mathrm{~km}$ (inner domain) (horizontal scale of $9^{\circ} \times 7^{\circ}$, Fig. 2a), and there are 18 vertical levels from the surface to $100 \mathrm{hPa}$. The lowest layer is about $30 \mathrm{~m}$ in depth. The simulation periods are 17 July-15 August 2003 during the IMPACT-2 campaign and 23 July-15 August 2004 during the IMPACT-L campaign. The first 2 days of data were used for model spin-up. The National Centers for Environmental Prediction (NCEP) Final (FNL) Operational Global Analysis data were used for initial and boundary conditions and nudging (free troposphere only) of meteorological fields. We performed two model simulations, with and without aging processes of organic vapors in the VBS.

We used anthropogenic emission inventories for 1998 at a horizontal resolution of $10 \mathrm{~km} \times 10 \mathrm{~km}$ with seasonal and diurnal dependencies (Kannari et al., 2004). The detailed description of the inventories is given by Matsui et al. (2009a). We also used online biogenic emissions: the Model of Emissions of Gases and Aerosols from Nature version 2 (MEGAN2) (Guenther et al., 2006). Using the same approach as described in Matsui et al. (2009a), the emissions of aromatics (toluene and xylene) and POA were increased or decreased over all of the simulation domains (without modification of the spatial emission patterns) to achieve good agreement between the observed and simulated mean concentrations of these species at the Komaba site during the IMPACT-2 campaign: ARO1 (toluene-like) and ARO2 (xylene-like) emissions were reduced by 50 and $30 \%$, respectively, and POA emissions were increased by $25 \%$. As the simulations with these modifications can reproduce mean concentrations of aromatics and POA during the simulation period, at least at and around Komaba, we can robustly evaluate the performance of OA formation processes. The modifications of emissions were applied to the simulations in and around Tokyo only. We did not use these modifications in the simulations over East Asia (Sect. 3.2).

\subsection{Simulation over East Asia (spring 2009)}

We used OA and sulfate mass concentrations observed with an Aerodyne AMS at Fukue $\left(32.75^{\circ} \mathrm{N}, 128.68^{\circ} \mathrm{E}\right)$ and Hedo $\left(26.87^{\circ} \mathrm{N}, 128.25^{\circ} \mathrm{E}\right)$, Japan, in March and April 2009 during the Aerosol Radiative Forcing in East Asia (A-FORCE) aircraft campaign (Oshima et al., 2012). As described by Takami et al. $(2005,2007)$, the collection efficiency was assumed to be 0.5 at Fukue and 1.0 at Hedo. Details of the AMS measurements at Fukue and Hedo are described by Takami et al. $(2005,2007)$. OA measurements over the outflow regions in East Asia are limited and are useful for evaluating the model simulations. The air parcels observed at Fukue and Hedo represent the histories of sources from wide areas over northern China and their histories during transport (e.g., Kondo et al., 2011; Matsui et al., 2013a), which suggests that model evaluations at these sites are suitable for the overall validations of aerosol sources, transport, and transformation from the Asian continent to the Pacific. We also used $\mathrm{BC}$ mass concentrations observed with a continuous soot 
Table 4. List of model simulations.

\begin{tabular}{|c|c|c|}
\hline \multirow[t]{2}{*}{ Simulation } & \multicolumn{2}{|c|}{$\begin{array}{c}\text { Aging coefficient } \\
\left(\mathrm{cm}^{3} \text { molecule }{ }^{-1} \mathrm{~s}^{-1}\right)\end{array}$} \\
\hline & $\begin{array}{l}\text { S / IVOCs and } \\
\text { anthropogenic OVOCs }\end{array}$ & $\begin{array}{l}\text { Biogenic } \\
\text { OVOCs }\end{array}$ \\
\hline Aging-on & $1 \times 10^{-11}$ & $1 \times 10^{-11}$ \\
\hline Aging-off & 0 & 0 \\
\hline Aging-an & $1 \times 10^{-11}$ & 0 \\
\hline Aging-bio & 0 & $1 \times 10^{-11}$ \\
\hline Aging-0.25 & $2.5 \times 10^{-12}$ & $2.5 \times 10^{-12}$ \\
\hline Aging-4 & $4 \times 10^{-11}$ & $4 \times 10^{-11}$ \\
\hline
\end{tabular}

monitoring system (COSMOS) to evaluate primary aerosols at Fukue and Hedo (Kondo et al., 2011).

For the simulation over East Asia, the horizontal grid spacings for the model domain are $180 \mathrm{~km}$ (outer domain) and $60 \mathrm{~km}$ (inner domain) (horizontal scale of $120^{\circ} \times 60^{\circ}$, Fig. 2b), and there are 26 vertical levels from the surface to $100 \mathrm{hPa}$. The lowest layer is about $30 \mathrm{~m}$ in depth. The simulation period is 21 March-26 April 2009 during the AFORCE aircraft campaign. The statistics are calculated for 24 March-26 April 2009 period. The NCEP-FNL data were used for initial and boundary conditions and nudging (free troposphere only) of meteorological fields. Our previous simulations using WRF-Chem successfully reproduced meteorological fields due to synoptic-scale meteorological variations and related transport and variation processes of aerosol mass and number concentrations observed by both the aircraft and surface measurements during the A-FORCE period (Matsui et al., 2013b, c). Our previous simulation using similar model settings also showed that the observed precipitation and its spatial distributions were generally reproduced by WRF during the simulation period (Oshima et al., 2013). Table 4 shows a list of the simulations over East Asia conducted in this study.

We used the anthropogenic and volcanic emission inventories of Streets et al. (2003), which were also used in our previous studies (Matsui et al., 2013b, c). $\mathrm{SO}_{2}$ emissions from the Miyakejima volcano were modified based on measurements, as shown by Matsui et al. (2013c). We also used daily biomass burning emissions from the Global Fire Emissions Database version 3 (GFED3) (van der Werf et al., 2010), and online biogenic emissions from MEGAN2. Sea salt and dust emissions from natural sources are not considered in this study.

Anthropogenic POA (from fossil fuel and biofuel combustion) is emitted mostly from China and India (Fig. 3a), while biomass burning POA is emitted mainly from Southeast Asia and Siberia (Fig. 3b). Anthropogenic and biomass burning sources account for 69 and $31 \%$ of total POA emissions, respectively. ARO1 (anthropogenic) emissions are distributed over China, India, Southeast Asia, Japan, and South Korea
(Fig. 3c). The main source regions of TERP (biogenic) are Southeast Asia and southern China (Fig. 3d).

\section{Model results and evaluation}

\subsection{IMPACT campaign (Tokyo)}

Figure $4 \mathrm{a}$ and $\mathrm{b}$ show the time series of $\mathrm{O}_{3}$ and $\mathrm{SOA}$ at Kisai during the IMPACT-L campaign (25 July-15 August 2004). Simulated SOA is the sum of OPOA, ASOA, and BSOA. Simulated concentrations in Sect. 4 were chosen from a grid cell closest to each measurement site and were calculated for particles with diameters of less than $1 \mu \mathrm{m}$. The data at the lowest layer were chosen for comparison with the surface measurements. Meteorological conditions during the campaign are summarized by Takegawa et al. (2006a). Northerly and easterly winds were dominant during 25-30 July, persistent southerly winds were dominant during 31 July-9 August (associated with a stable anticyclone located east of Tokyo), and the sea-land breeze circulation was dominant during 1014 August (associated with a stable anticyclone over Tokyo). Due to these meteorological conditions, relatively fresh air was transported from the Tokyo metropolitan area to Kisai by 9 August, which resulted in relatively low $\mathrm{O}_{3}$ and SOA concentrations at Kisai. In contrast, stagnant and aged air was transported to Kisai during 10-14 August, which enhanced $\mathrm{O}_{3}$ and SOA concentrations at Kisai due to the accumulation of pollutants.

The simulation reproduces the absolute concentrations and the diurnal and day-to-day variations of observed $\mathrm{O}_{3}$ and SOA concentrations reasonably well (Fig. 4 and Table 5). In particular, the model reproduces the contrast between the early (25 July-6 August, low concentrations) and the later (7-15 August, high concentrations) simulation periods and the diurnal peak concentrations of both $\mathrm{O}_{3}$ and SOA (Fig. 4). The daytime peak concentrations of $\mathrm{OH}$ and $\mathrm{HO}_{2}$ radicals are also reproduced by within $50 \%$ at Komaba during the IMPACT-L campaign in our simulations, though the concentrations have large day-to-day variability: the median values of the daytime peak concentrations of observed $\mathrm{OH}$ and $\mathrm{HO}_{2}$ were $6.3 \times 10^{6} \mathrm{~cm}^{-3}$ and $5.7 \mathrm{pptv}$, respectively (Kanaya et al., 2007), and those of simulated $\mathrm{OH}$ and $\mathrm{HO}_{2}$ were $9.8 \times 10^{6} \mathrm{~cm}^{-3}$ and $6.8 \mathrm{pptv}$, respectively.

As both $\mathrm{O}_{3}$ and SOA were produced by photochemical reactions during the IMPACT-2 and IMPACT-L campaigns, the $\mathrm{SOA} / \mathrm{O}_{3}$ ratio can be used as an index of OA formation efficiency under given oxidative conditions (Fig. 5) (Herndon et al., 2008; Kondo et al., 2008). The model simulation tends to overestimate maximum SOA concentrations during daytime and underestimate SOA concentrations during nighttime. However, mean SOA concentrations are reproduced by the model to within $25 \%$ of the corresponding observed values (underestimations of 21 and $13 \%$ during the IMPACT-2 and IMPACT-L campaigns, respectively) 
(a)

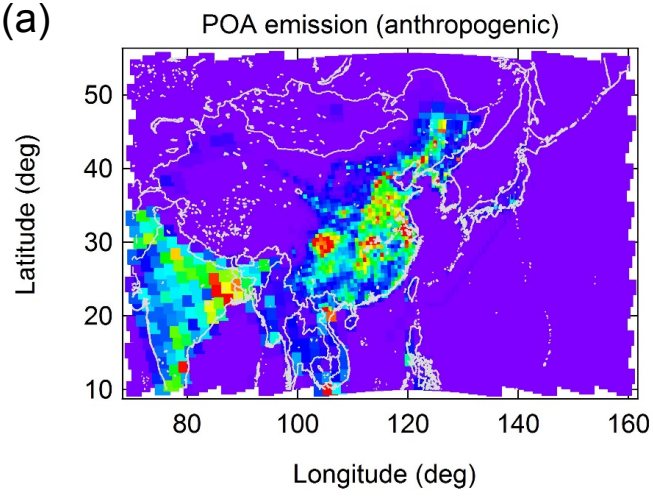

(c)

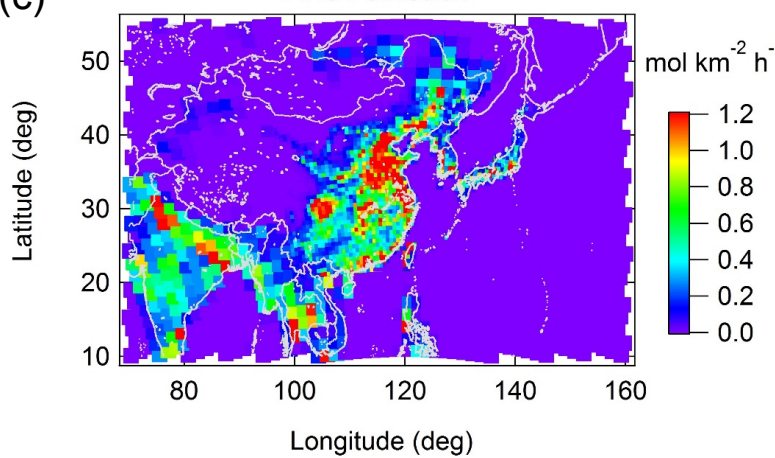

(b)

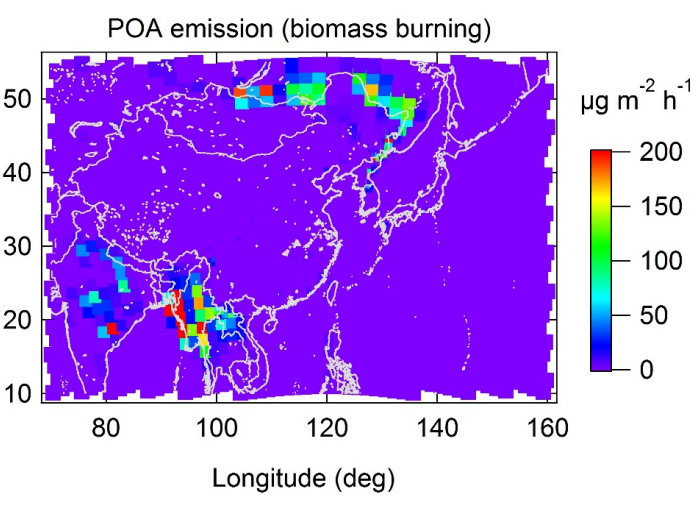

(d)

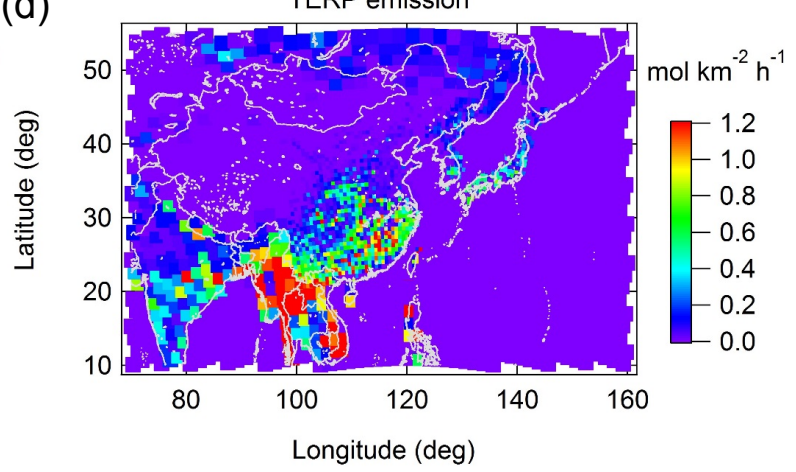

Figure 3. Period-averaged (24 March-26 April 2009) emissions for (a) POA from anthropogenic sources (fossil fuel and biofuel combustion), (b) POA from biomass burning sources, (c) ARO1 (aromatics), and (d) TERP (monoterpenes). We used the anthropogenic and volcanic emission inventories of Streets et al. (2003), daily biomass burning emissions of the Global Fire Emissions Database version 3 (GFED3) (van der Werf et al., 2010), and online biogenic emissions of the Model of Emissions of Gases and Aerosols from Nature version 2 (MEGAN2) (Guenther et al., 2006).

(Table 5). In both campaigns, the simulated fitting slopes (with aging processes) are consistent with the observed slopes (and hence OA formation efficiency): the observed and simulated fitting slopes are 0.16 and 0.19 , respectively, during the IMPACT- 2 campaign and 0.15 and 0.20 , respectively, during the IMPACT-L campaign.

The simulation without aging processes (orange lines and triangles in Figs. 4 and 5), which is similar to the simulation using a traditional OA model, severely underestimates mean observed OA concentrations by 76 and $86 \%$ and fitting slopes by 80 and $82 \%$ during the IMPACT- 2 and IMPACT-L campaigns, respectively. These results show that the emissions of S / IVOCs and the oxidation processes of organic vapors (S / IVOCs and OVOCs) must be considered for reasonable OA simulations in and around Tokyo: including these in the VBS scheme considerably improved the model's ability to simulate $\mathrm{OA}$ absolute concentrations and their temporal variations in Tokyo and its outflow area at Kisai.

In our simulations, SOA is formed mainly from anthropogenic sources at Komaba and Kisai $(77-80 \%$ of total SOA). The three largest precursors of SOA are aromatics (ARO1 and ARO2, 48\%), olefins (OLE1 and OLE2, 13$18 \%$ ), and monoterpenes (TERP, $13-16 \%$ ). OPOA accounts for only $6-7 \%$ of total SOA at both sites during the simulation periods.

\subsection{A-FORCE periods (East Asia)}

Figure 6a-d show the time series of $\mathrm{BC}$ and $\mathrm{SO}_{4}$ at the Fukue and Hedo sites during the A-FORCE campaign (24 March-26 April 2009). The meteorological conditions during this period are described by Matsui et al. $(2013 b, c)$. Synoptic-scale meteorological variations controlled temporal variations of observed aerosol concentrations at Fukue and Hedo: high concentrations during the period covered by a high-pressure system and rapid decreases in concentrations after the passage of a cold front. At Fukue, the site was covered by a high-pressure system during the middle of the simulation period (6-12 April), and cold fronts passed on 14, 20, and 24 April. The temporal variations of observed BC and $\mathrm{SO}_{4}$ due to synoptic-scale meteorological variations are generally reproduced by the model simulation. The mean BC concentrations are reproduced well by the model at Fukue and Hedo (normalized mean bias (NMB) of $-14 \%$ at Fukue and $-24 \%$ at Hedo). The mean $\mathrm{SO}_{4}$ concentrations at Fukue are also reproduced well by the model (NMB of $-11 \%$, Table 5), while those at Hedo are overestimated by a factor of 


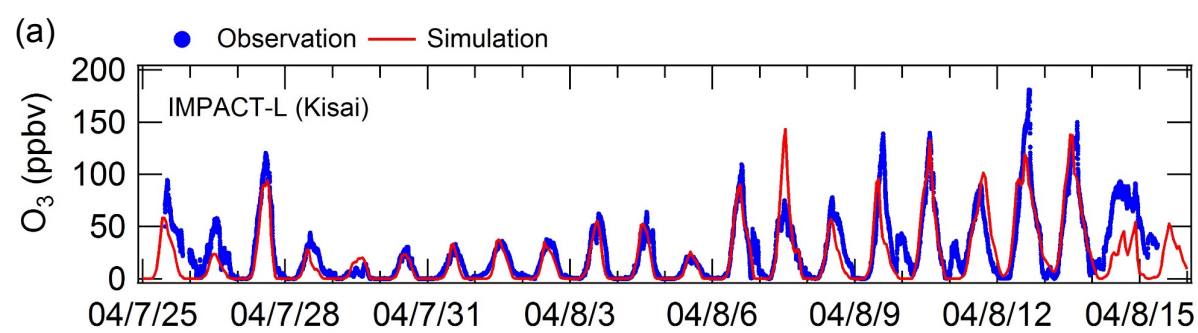

(b)

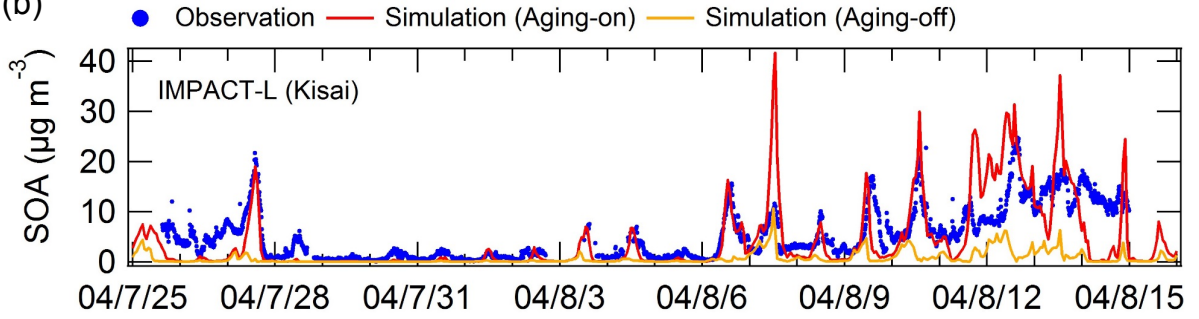

Figure 4. Time series of the observed and simulated (a) $\mathrm{O}_{3}$ volume mixing ratios and (b) SOA mass concentrations at Kisai during the IMPACT-L campaign. SOA values were simulated with and without aging.

Table 5. Statistics of concentrations of chemical species at the surface measurement sites.

\begin{tabular}{|c|c|c|c|c|c|c|c|c|}
\hline \multirow[t]{2}{*}{ Station } & \multirow[t]{2}{*}{ Period } & \multirow[t]{2}{*}{ Species } & \multirow[t]{2}{*}{ Units } & \multicolumn{3}{|c|}{ Mean concentration } & \multirow{2}{*}{$\begin{array}{r}\text { NMB } \\
(\%)^{b}\end{array}$} & \multirow[t]{2}{*}{$R^{\mathrm{b}}$} \\
\hline & & & & Observation & $\begin{array}{l}\text { Calculation }^{\mathrm{a}} \\
\text { (Aging-on) }\end{array}$ & $\begin{array}{l}\text { Calculation }^{\mathrm{a}} \\
\text { (Aging-off) }\end{array}$ & & \\
\hline \multirow[t]{2}{*}{ Komaba } & 19 July-13 August 2003 & $\mathrm{O}_{3}$ & $\mathrm{ppbv}$ & 19.6 & 15.3 & 15.4 & -22.3 & 0.63 \\
\hline & (IMPACT-2) & SOA & $\mu \mathrm{g} \mathrm{m}^{-3}$ & 4.36 & 3.45 & 1.03 & -20.8 & 0.52 \\
\hline \multirow[t]{2}{*}{ Kisai } & 25 July-14 August 2004 & $\mathrm{O}_{3}$ & ppbv & 26.4 & 20.6 & 20.7 & -21.9 & 0.84 \\
\hline & $($ IMPACT-L) & SOA & $\mu \mathrm{g} \mathrm{m}^{-3}$ & 5.31 & 4.61 & 0.76 & -13.1 & 0.70 \\
\hline \multirow[t]{4}{*}{ Fukue } & 27 March-26 April 2009 & $\mathrm{BC}$ & $\mu \mathrm{g} \mathrm{m}^{-3}$ & 0.87 & 0.75 & 0.74 & -14.2 & 0.76 \\
\hline & & $\mathrm{SO}_{4}$ & $\mu \mathrm{g} \mathrm{m}^{-3}$ & 9.31 & 8.29 & 8.27 & -10.9 & 0.65 \\
\hline & & $\mathrm{OA}$ & $\mu \mathrm{g} \mathrm{m}^{-3}$ & 6.02 & 6.75 & 0.71 & 12.2 & 0.34 \\
\hline & & $\mathrm{OA} / \mathrm{SO}_{4}$ & - & 0.89 & 0.78 & 0.13 & -11.9 & 0.28 \\
\hline \multirow[t]{4}{*}{ Hedo } & 24 March-26 April 2009 & $\mathrm{BC}$ & $\mu \mathrm{g} \mathrm{m}^{-3}$ & 0.36 & 0.27 & 0.27 & -24.3 & 0.46 \\
\hline & & $\mathrm{SO}_{4}$ & $\mu \mathrm{g} \mathrm{m}^{-3}$ & 2.36 & 4.20 & 4.24 & 78.0 & 0.34 \\
\hline & & $\mathrm{OA}$ & $\mu \mathrm{g} \mathrm{m}^{-3}$ & 1.08 & 1.99 & 0.18 & 84.2 & 0.25 \\
\hline & & $\mathrm{OA} / \mathrm{SO}_{4}$ & - & 0.58 & 0.42 & 0.058 & -29.7 & 0.58 \\
\hline
\end{tabular}

${ }^{a}$ Values are calculated for the periods when measurements are available.

b Statistics are calculated for the Aging-on simulation.

2 during the middle and latter parts of the simulation period (NMB of $78 \%$, Table 5).

Figure $6 \mathrm{e}$ and $\mathrm{f}$ show the time series of $\mathrm{OA}$ at Fukue and Hedo during the A-FORCE period. At both sites, most of the measured OA was OOA and most of the simulated OA was SOA (shown below). The temporal variations of $\mathrm{OA}$ are generally similar to those of $\mathrm{SO}_{4}$ at both sites. At Fukue, the model overestimates OA concentrations during 715 April but underestimates them during 28 March-2 April. The model reproduces observed OA concentrations well during the other periods. The period-averaged OA concentrations are slightly overestimated (NMB of $12 \%$, Table 5), but the model simulations agree well with the measurements.
At Hedo, simulated OA concentrations are overestimated by $80 \%$ (Table 5 ). The period of OA overestimation corresponds to the period of $\mathrm{SO}_{4}$ overestimation. Therefore, it is unlikely that the problems in $\mathrm{OA}$ formation processes are the only factors that made the discrepancy between observed and simulated OA concentrations. The model may overestimate the transport of pollutants, including precursor species and secondary aerosol formation from them. The uncertainties in the AMS measurements may also contribute to the discrepancy between the measurements and model simulations because the observed OA concentrations at Hedo are the lower limit in terms of the collection efficiency (Sect. 3.2). 
The observed OOA / OA ratio was estimated to be greater than $95 \%$ at Fukue and Hedo (Zhang et al., 2007). The simulated SOA/OA ratio is $84 \%$ at Fukue and $83 \%$ at Hedo, suggesting that our model simulations tend to underestimate the fraction of SOA to total OA at these measurement sites.

Figure $6 \mathrm{~g}$ and $\mathrm{h}$ show the time series of $\mathrm{OA} / \mathrm{SO}_{4}$ ratio at Fukue and Hedo during the A-FORCE period. The OA/ $\mathrm{SO}_{4}$ ratio is used because both $\mathrm{OA}$ and $\mathrm{SO}_{4}$ at these sites are formed through oxidation processes in the atmosphere. Their oxidation pathways may not be the same (OA is formed from gas-phase oxidation only, but $\mathrm{SO}_{4}$ is formed from both gasphase and aqueous-phase oxidation in our model), but as the formation processes of $\mathrm{SO}_{4}$ are relatively well known compared with those of $\mathrm{OA}$, the $\mathrm{OA} / \mathrm{SO}_{4}$ ratio can be used as an index of OA formation efficiency relative to the amounts of secondary aerosols transported to the measurement sites. The model reproduces the period-averaged $\mathrm{OA} / \mathrm{SO}_{4}$ ratio observed at Fukue and Hedo reasonably well: the observed ratios are 0.89 and 0.58 , and the simulated ratios are 0.78 (NMB of $-12 \%)$ and 0.42 (NMB of $-30 \%$ ), respectively (Table 5).

In contrast, the simulation without aging processes do not capture observed OA mass concentrations and $\mathrm{OA} / \mathrm{SO}_{4} \mathrm{ra}-$ tios. The model without aging processes considerably underestimates both the OA concentrations (by 88 and $83 \%$ ) and the $\mathrm{OA} / \mathrm{SO}_{4}$ ratio (by 85 and $90 \%$ ) at Fukue and Hedo, respectively. These results demonstrate that the VBS scheme with aging processes much improves the model performance; the scheme realistically simulated OA mass concentrations and their temporal variations and the $\mathrm{OA} / \mathrm{SO}_{4}$ ratio over the outflow regions in East Asia.

Simulated SOA is formed mostly from anthropogenic sources at Fukue and Hedo (90-91\% of total SOA). The three largest sources are aromatics (ARO1 and ARO2, 41$46 \%$ ), S / IVOCs (34-41\%), and monoterpenes (TERP, 7$8 \%$ ). The contributions of OPOA at Fukue and Hedo (34$41 \%$ of total SOA) are much higher than those at Komaba and Kisai (6-7 \% of total SOA), due to continuous aging processes of organic vapors during transport from source areas to the measurement sites at Fukue and Hedo.

The uncertainties in the aging coefficients of S/IVOCs are very large in the VBS scheme. To understand the impact of these uncertainties on simulated OA mass concentrations, we conducted sensitivity simulations using aging coefficients of $4 \times 10^{-11} \mathrm{~cm}^{3}$ molecule ${ }^{-1} \mathrm{~s}^{-1}$ (4 times the base case, "Aging-4") and $2.5 \times 10^{-12} \mathrm{~cm}^{3}$ molecule $^{-1} \mathrm{~s}^{-1}(1 / 4$ of the base case, "Aging-0.25") (Fig. 6e and f, Table 4). The Aging-4 (Aging-0.25) simulation increased (decreased) period-averaged OA mass concentrations by factors of 3.2 (2.1) and 4.1 (2.4) at Fukue and Hedo, respectively; thus simulated OA concentrations over East Asia are greatly affected by the choice of aging coefficients. Therefore, it is important to improve our understanding of the oxidation processes of organic vapors by using laboratory and field measurements and by applying and validating the VBS scheme for various atmospheric conditions.

\section{Spatial distribution of OA over East Asia}

\subsection{Impact of aging processes}

\subsubsection{Mass concentrations and contributions}

Next, we examine the spatial distributions of OA over East Asia. In Sect. 5, all particles between $40 \mathrm{~nm}$ and $10 \mu \mathrm{m}$ in diameter were used to calculate OA concentrations. For the simulation with the aging process, POA concentrations at an altitude of about $1 \mathrm{~km}$ peak over Southeast Asia and northern and central China (Fig. 7a), corresponding to large source regions of biomass burning and anthropogenic emissions, respectively (Fig. 3a and b). The spatial distribution of OPOA is similar to that of POA (Fig. 7c). ASOA concentrations are high over northern and central China and moderate over southern China, Japan, and Southeast Asia (Fig. 7e). The maximum of BSOA concentration is over Southeast Asia and southern China (Fig. 7g). Total SOA (OPOA + ASOA + BSOA) concentrations are distributed widely over East Asia, with peaks over Southeast Asia and northern and central China (Fig. 7i).

The large contribution of BSOA over southern China and Southeast Asia is consistent, at least qualitatively, with previous OA modeling studies (Han et al., 2008; Jiang et al., 2012; Li et al., 2013), in which 65-90\% of SOA in southern China was estimated to be biogenic. Several measurement studies have reported mean organic carbon (OC) concentrations in spring over Guangzhou in southern China of $6-7 \mu \mathrm{g} \mathrm{m}^{-3}$ (Tao et al., 2012; Huang et al., 2012), over Hong Kong of 6 $9 \mu \mathrm{g} \mathrm{m}^{-3}$ (Bahadur et al., 2009), and over Bangkok of about $10 \mu \mathrm{g} \mathrm{m}^{-3}$ (Sahu et al., 2011). We compared our simulation results with these measurements, though the meteorological conditions, the amounts of emissions (e.g., biomass burning, biogenic), or both may have differed between those studies and ours. When we assume an OC-to-OA conversion rate of 1.6 (Turpin and Lim, 2001), our simulations underestimate observed OA concentrations by $35 \%$ at Guangzou and by $60-70 \%$ at Hong Kong and Bangkok. OOA concentrations in the Pearl River delta region observed with an AMS have also been reported: about $5 \mu \mathrm{g} \mathrm{m}^{-3}$ in summer 2006 (Xiao et al., 2011) and in fall 2009 (Li et al., 2013). Our simulations underestimate the observed SOA concentrations by $30-40 \%$ in this region. The rough comparisons shown above suggest that our OA and SOA simulations over southern China and Southeast Asia are consistent with measurements within a factor of 3 (underestimation by 30-70\%). The agreement between the measurements and model simulations over southern China and Southeast Asia was much improved by considering aging processes of organic vapors in the VBS scheme. 



Figure 5. Correlation of SOA mass concentrations with $\mathrm{O}_{3}$ volume mixing ratios (a) at Komaba during the IMPACT-2 campaign and (b) at Kisai during the IMPACT-L campaign. Solid lines show the fitting slopes $(y=a x)$ for observation (blue) and simulations with (red) and without (orange) aging processes of organic vapors.
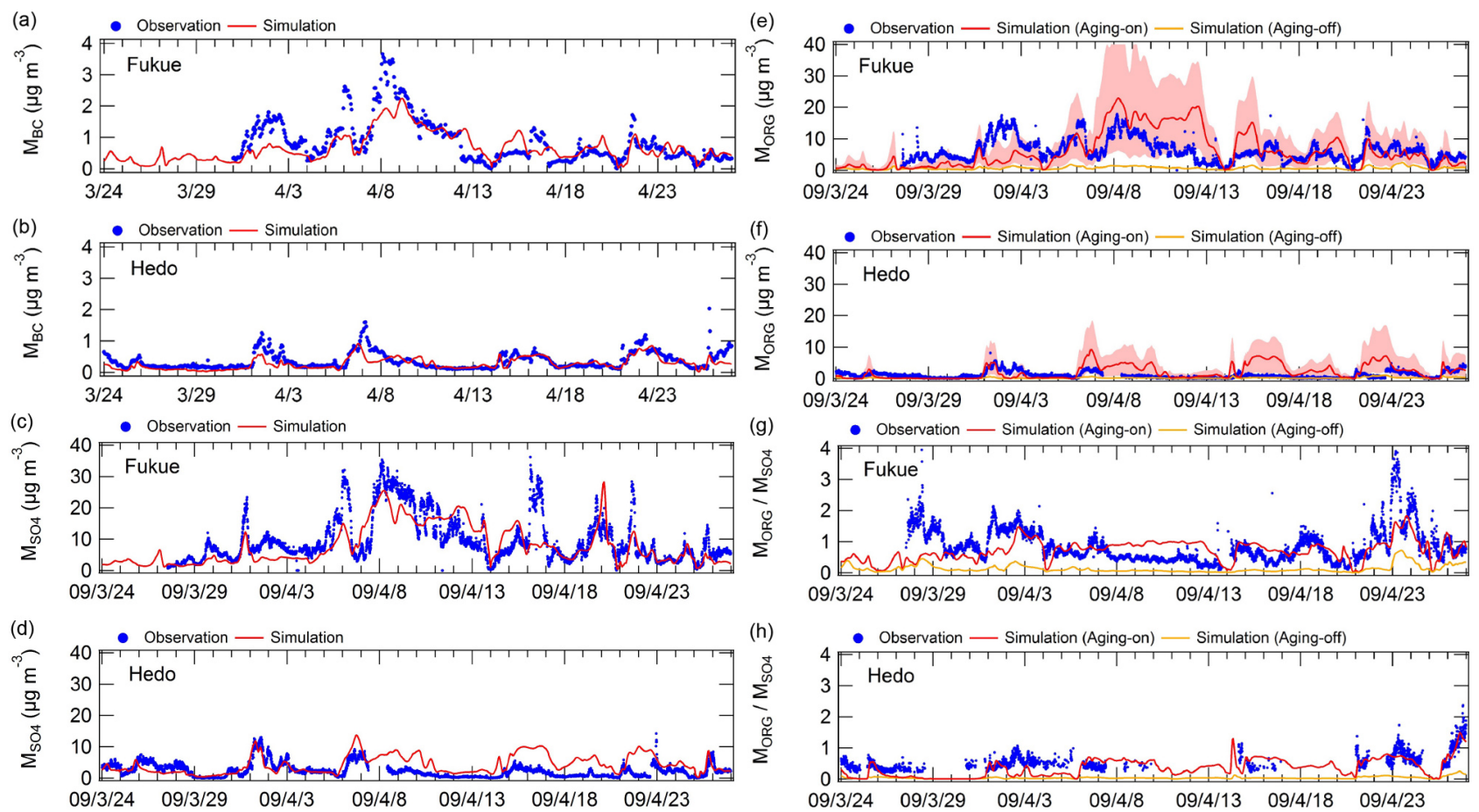

Figure 6. Time series of $(\mathbf{a}, \mathbf{b})$ black carbon mass concentrations, $(\mathbf{c}, \mathbf{d})$ sulfate mass concentrations, $(\mathbf{e}, \mathbf{f})$ organic aerosol mass concentrations, and $(\mathbf{g}, \mathbf{h})$ organic to sulfate mass concentration ratios at Fukue and Hedo, respectively. Red shading in (e) and (f) shows the range of organic aerosol mass concentrations with the aging coefficients of between $4 \times 10^{-11} \mathrm{~cm}^{3}$ molecule $\mathrm{s}^{-1}$ ( 4 times the base case) and $2.5 \times 10^{-12} \mathrm{~cm}^{3}$ molecule ${ }^{-1} \mathrm{~s}^{-1}(0.25$ times the base case $)$. The periods when observed sulfate mass concentrations were less than $1 \mu \mathrm{g} \mathrm{m}^{-3}$ are not shown for measurements (blue points) in (g) and (h).

SOA concentrations in the Aging-off simulation are much lower than those in the Aging-on simulation (Fig. 7). By considering aging processes, ASOA, BSOA, OPOA, total SOA, and total OA concentrations increased by between 440 and $1380 \%$ over the outer domain (Fig. 8a and Table 6), demonstrating the importance of aging processes in OA simulations for East Asia. POA concentrations, however, vary less: the Aging-on POA concentrations over the outer domain are about $30 \%$ more than those for the Aging-off simulations (Fig. 8a and Table 6). The lower POA concentrations in the 
(a)

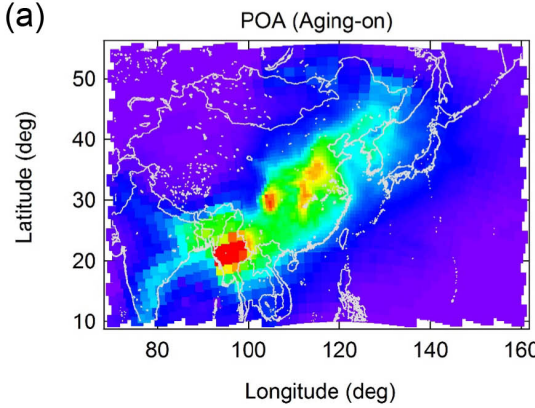

(c)

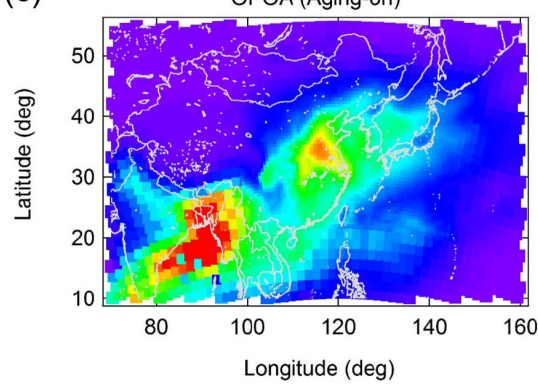

(e)

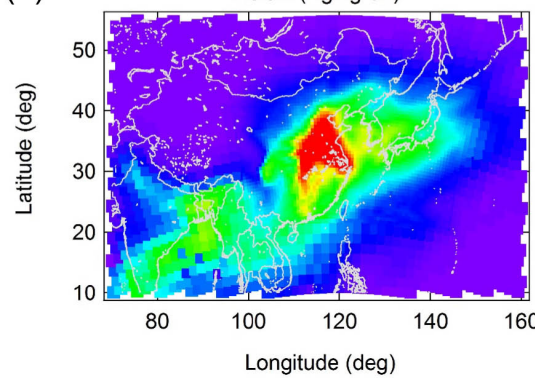

(g)

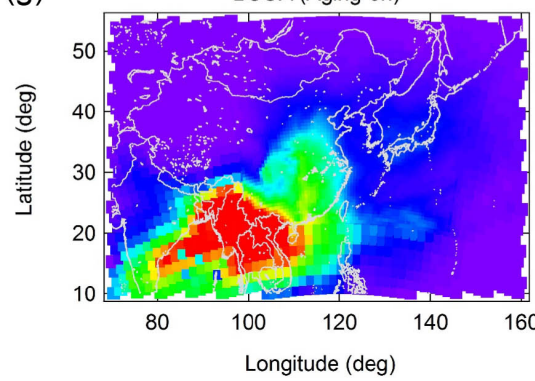

(i)

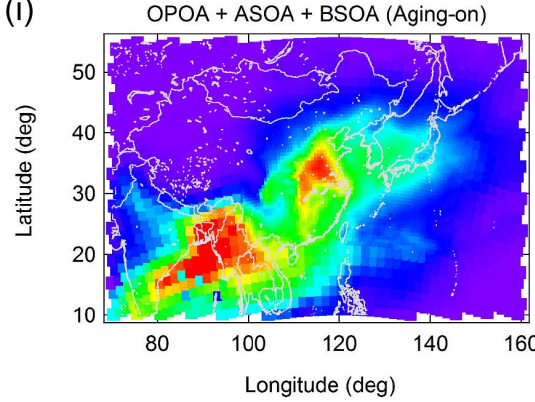

(b)
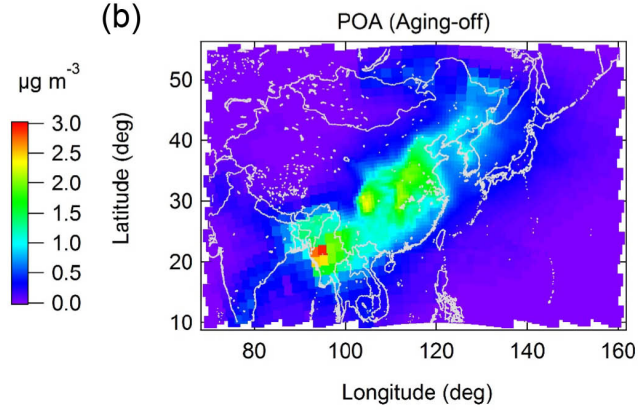

(d)

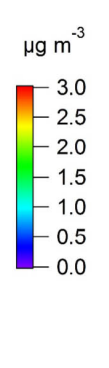

$$
\text { (d) }
$$

(f)
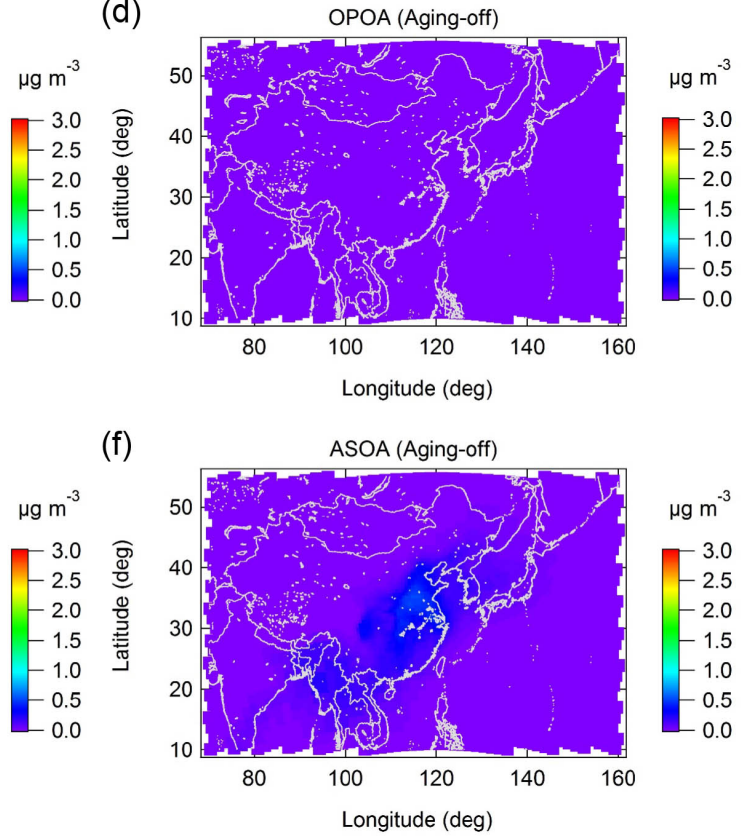

(h)
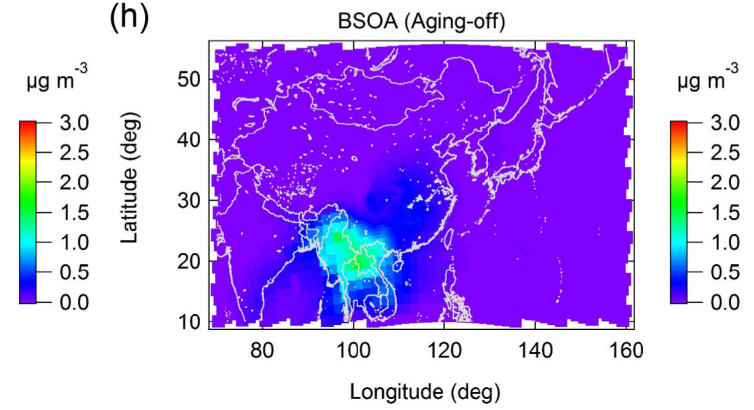

(j)
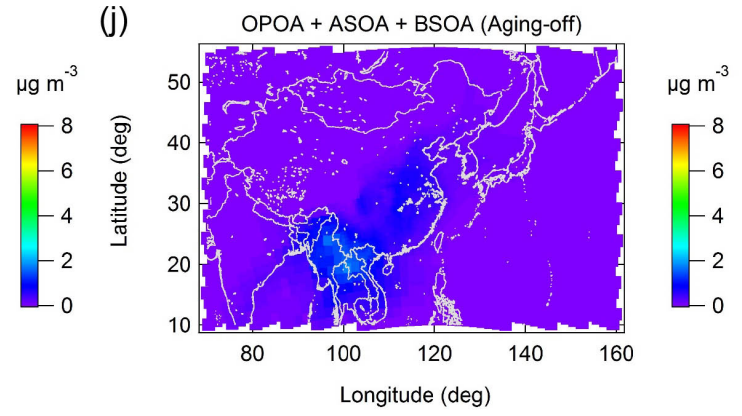

Figure 7. Period-averaged (24 March-26 April 2009) simulated mass concentrations of POA (a, b), OPOA (c, d), ASOA (e, f), BSOA (g, h), and total SOA (sum of OPOA, ASOA, and BSOA) (i, j) at an altitude of about $1 \mathrm{~km}$ (layer number of 8 , sigma level of 0.895). Left panels $(\mathbf{a}, \mathbf{c}, \mathbf{e}, \mathbf{g}, \mathbf{i})$ are runs with aging, and right panels $(\mathbf{b}, \mathbf{d}, \mathbf{f}, \mathbf{h}, \mathbf{j})$ are runs without aging. 
Table 6. Period-averaged organic aerosol mass concentration $\left(\mu \mathrm{g} \mathrm{m}^{-3}\right)$ in the boundary layer $(\sim 1 \mathrm{~km})$ over the outer domain.

\begin{tabular}{lccccc}
\hline Simulation & POA & OPOA & ASOA & BSOA & Total OA \\
\hline Aging-on & 0.236 & 0.369 & 0.333 & 0.346 & 1.284 \\
Aging-off & 0.164 & 0.000 & 0.023 & 0.048 & 0.236 \\
Aging-an & 0.229 & 0.357 & 0.313 & 0.111 & 1.004 \\
Aging-bio & 0.196 & 0.000 & 0.038 & 0.241 & 0.474 \\
Aging-0.25 & 0.188 & 0.056 & 0.106 & 0.132 & 0.483 \\
Aging-4 & 0.275 & 1.223 & 0.661 & 0.654 & 2.813 \\
Aging-on (an off)* & 0.047 & 0.035 & 0.007 & 0.075 & 0.165 \\
Aging-off (an off)* & 0.040 & 0.000 & 0.001 & 0.018 & 0.059 \\
\hline * Simulations without anthropogenic emissions (with biomass burning, biogenic, and volcanic
\end{tabular}
emissions).

Aging-off simulation are likely due to the smaller amounts of low-volatility organic vapors, which are produced by $\mathrm{OH}$ oxidation in the Aging-on simulation, and the resulting reduction of OA concentrations in the particulate phase due to the shift of the gas-particle partitioning to the gas phase.

In addition to differences in the absolute mass concentrations, the contributions from individual chemical compositions to total OA also differ greatly between the Aging-on and Aging-off simulations (Fig. 8b and c). In the Aging-on simulation, POA, OPOA, ASOA, and BSOA account for $18,29,26$, and $27 \%$ of OA, respectively, over the outer domain. The main precursors of ASOA are aromatics (ARO1 and ARO2, $80 \%$ of ASOA), and those of BSOA are monoterpenes (TERP, $55 \%$ of BSOA). In the aging-off simulation, POA is dominant (70\% of total OA) due to the formation of much lower concentrations of ASOA and BSOA with no OPOA.

\subsubsection{Sensitivity of aging parameters over East Asia}

Table 6 shows the results of the Aging- 4 and Aging- 0.25 simulations. Similar to the results at Fukue and Hedo (Sect. 4.2), SOA concentrations are highly sensitive to aging coefficients over the simulation domain. The period-averaged mass concentrations of OPOA, ASOA, and BSOA were enhanced (reduced) by factors of 3.3 (6.6), 2.0 (3.1), and 1.9 (2.6), respectively, in the Aging-4 (Aging-0.25) simulation over the whole East Asian region (Table 6a). In contrast, POA concentrations are not so sensitive to the aging coefficients. The average POA concentrations increased by $17 \%$ in the Aging4 simulation and decreased by $26 \%$ in the Aging- 0.25 simulation, both relative to the Aging-on (base) simulation.

Increasing the rate constant by a factor of 4 enhances OPOA concentrations (increase by a factor of 3.3) more than ASOA concentrations (increase by a factor of 2). IVOCs and their aging processes may contribute to the difference in the enhancement between OPOA and ASOA because primary and oxygenated S / IVOCs concentrations in the high volatility $\left(C^{*}\right.$ of $\left.10^{6}-10^{2} \mu \mathrm{g} \mathrm{m}^{-3}\right)$ are lower in the Aging-4 simulation relative to the Aging-on simulation (not shown).

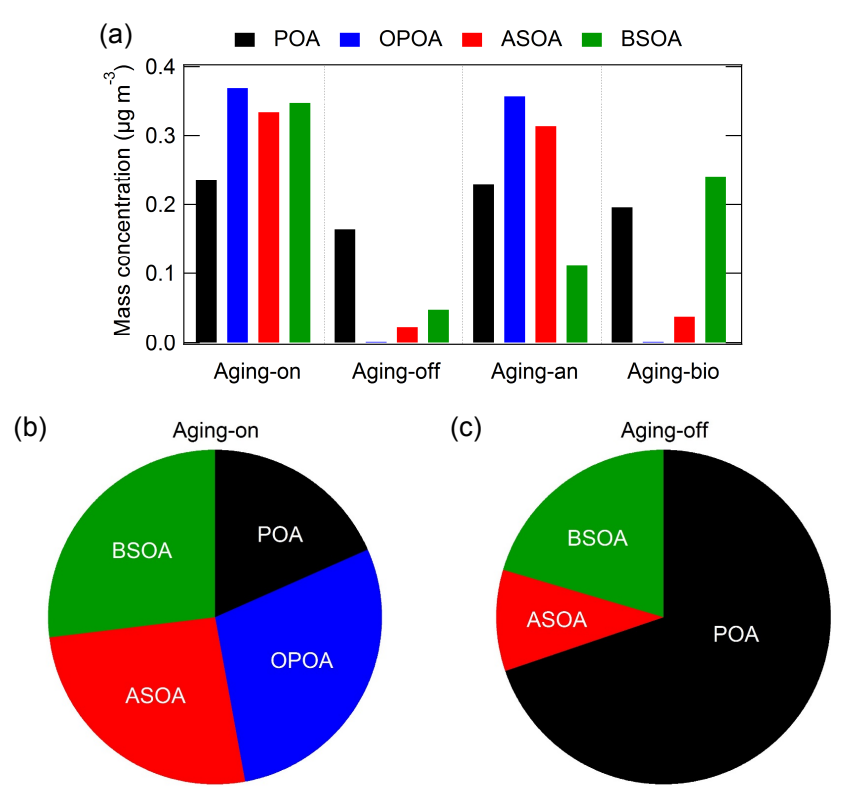

Figure 8. Period-averaged (24 March-26 April 2009) mass concentrations of POA, OPOA, ASOA, and BSOA at an altitude of about $1 \mathrm{~km}$ over the outer domain for Aging-on, Aging-off, Aging-bio, and Aging-an simulations (a). Period-averaged fraction of POA, OPOA, ASOA, and BSOA to total OA mass concentrations at an altitude of about $1 \mathrm{~km}$ over the outer domain for simulations with (b) or without (c) aging.

OPOA increases from the Aging-on to the Aging-4 simulation mostly due to the faster aging processes of primary and secondary S / IVOCs. ASOA (BSOA) increases from the Aging-on to the Aging-4 simulation due to the faster aging processes of both anthropogenic OVOCs (biogenic OVOCs) and S/IVOCs. The contribution of S/IVOCs aging processes to ASOA and BSOA increases is about one-third of total increases in ASOA and BSOA concentrations from the Aging-on to the Aging-4 simulation (not shown).

\subsubsection{Interaction of anthropogenic and biogenic sources}

The sensitivity simulations shown in Sects. 5.1.3 and 5.2 are summarized in Fig. 9. The simulation results with aging processes from biogenic sources only (no aging treatment for S / IVOCs and anthropogenic OVOCs) are shown in Fig. 8a and Table 6 (the Aging-bio simulation in Table 4). The contribution of aging processes from anthropogenic sources (AN-aging) can be estimated from the difference in OA concentrations between the Aging-on (base case) and Aging-bio simulations (Fig. 9). As expected, the impact of AN-aging on OPOA and ASOA over the outer domain is very large: AN-aging increases OPOA concentrations from 0.0 to $0.37 \mu \mathrm{g} \mathrm{m}^{-3}$ and ASOA concentrations from 0.038 to $0.33 \mu \mathrm{g} \mathrm{m}^{-3}$ (+780\%) (Table 6). AN-aging also moderately enhances POA concentrations $(+20 \%$, Table 6). 
BSOA concentrations are also enhanced considerably $(+45 \%)$ by $\mathrm{AN}$-aging (Table 6$)$. This is because AN-aging produces large amounts of low-volatility organic vapors and OA from anthropogenic VOCs and S/IVOCs, and these vapors shift the gas-particle partitioning ratio of BSOA to the particulate phase. Therefore, AN-aging is very important for OA formation from both anthropogenic and biogenic sources.

These results show that BSOA concentrations are substantially enhanced by $\mathrm{OA}$ models that can represent realistic OA concentrations from anthropogenic $\mathrm{OA}$ in the atmosphere (the VBS scheme in this study), even if we do not change the treatment of BSOA formation processes in the model. In this study, the importance of this effect was shown for springtime over East Asia, where anthropogenic and biogenic emissions interact closely. Similar interaction is expected over other large emission sources such as the United States and Europe, implying the importance of AN-aging to BSOA concentrations on hemispherical and global scales. Therefore, to obtain more accurate simulations of BSOA, which is considered to be dominant globally, it is important to use a realistic OA formation scheme for anthropogenic sources.

Figure $8 \mathrm{a}$ also shows the simulation results with aging processes from anthropogenic sources only (the Aging-an simulation in Table 4). We can estimate the contribution of aging processes from biogenic sources (BIO-aging) by the difference in OA between the Aging-on (base case) and Agingan simulations (Fig. 9). BIO-aging slightly influences (less than 4-7\%) POA, OPOA, and ASOA, whereas it is important for BSOA ( $210 \%$ increase). Therefore, the enhancement of anthropogenic OA by aging processes of biogenic VOCs is limited. The difference in the importance of $\mathrm{AN}$-aging and BIO-aging is because anthropogenic sources are dominant over East Asia (Fig. 8b).

\subsection{Estimation of controllable $\mathrm{OA}$}

We estimate the contribution of $\mathrm{OA}$ influenced by anthropogenic emission sources (i.e., controllable OA). Here, we assume that biomass burning emissions are not anthropogenic (noncontrollable) sources, following the treatment in Carlton et al. (2010). To estimate the contribution of controllable OA over East Asia, we conducted sensitivity simulations with various amounts of anthropogenic emissions ranging from 0 to $200 \%$ of base case emissions for both gaseous $\left(\mathrm{CO}, \mathrm{NO}_{\mathrm{x}}, \mathrm{SO}_{2}, \mathrm{VOCs}\right.$, and primary $\left.\mathrm{S} / \mathrm{IVOCs}\right)$ and aerosol species (POA and $\mathrm{BC}$ ). Other settings are similar to the base case simulation. Biomass burning, biogenic, and volcanic emissions are not changed in these sensitivity simulations.

Period-averaged POA, OPOA, and ASOA concentrations normalized by those in the base case simulation increase almost linearly with anthropogenic emissions over the outer domain in the sensitivity simulations, except for the range of anthropogenic emissions from 0 to $50 \%$, where the contributions from biomass burning sources are dominant (Fig. 10).
In the simulation without anthropogenic emissions, POA, OPOA, and ASOA decrease to 20,9 , and $2 \%$, respectively, of the base case simulation. This is because the reduction of anthropogenic VOCs, $\mathrm{NO}_{\mathrm{x}}$, and POA reduces OA concentrations by changing VOC concentrations, their oxidation rates, and the gas-particle partitioning of organic compounds. Controllable OA concentrations can be estimated from the differences in OA between the simulations with (100\%) and without $(0 \%)$ anthropogenic emissions (Fig. 9). The fractions of controllable POA, OPOA, and ASOA are 80, 91, and $98 \%$, respectively, in our simulations over all of East Asia.

The fractions of POA, OPOA, and ASOA in the simulation without anthropogenic emissions $(20,9$, and $2 \%$ of the base case) are smaller than the fractions expected from emissions, because biomass burning sources account for $30 \%$ of POA emissions and $10 \%$ of aromatics emissions over the outer domain (Fig. 3c and d). An important reason for these smaller fractions is the lower $\mathrm{OH}$ concentrations (by a factor of 3 ) and the resulting slower oxidation rates of organic vapors in the simulation without anthropogenic emissions compared with the base case simulation. In fact, the fraction of lowvolatility organics (sum of vapors and aerosols) is smaller in the simulation without anthropogenic emissions (not shown).

BSOA mass concentrations are positively related to the amounts of anthropogenic emissions, though the relationship is weaker than the relationships for POA, OPOA, and ASOA (green line in Fig. 10). The fraction of controllable BSOA is $78 \%$ in our estimation; thus a large portion of BSOA is formed through the influence of anthropogenic sources (the enhancement of anthropogenic $\mathrm{VOCs}, \mathrm{NO}_{\mathrm{x}}$, and preexisting OA) over East Asia.

The period-averaged controllable OA concentrations over the outer domain are $1.12 \mu \mathrm{g} \mathrm{m}^{-3}$ and are higher than the sum of POA, OPOA, and ASOA concentrations $\left(0.94 \mu \mathrm{g} \mathrm{m}^{-3}\right)$. The fraction of controllable OA is $87 \%$ (Fig. 11a), suggesting that most of $\mathrm{OA}$ is controllable and formed anthropogenically in springtime over all of East Asia. The fraction of controllable OA is more than $90 \%$ over most of India and China and its outflow regions and 60-80\% over Southeast Asia, where BSOA concentrations are high (Fig. 11c), though $\mathrm{S} /$ IVOCs emissions and their aging processes have large uncertainties (Sect. 2.3). The fraction of controllable $\mathrm{PM}_{2.5}$ is $92 \%$ in our estimation, though dust and sea salt from natural sources are not considered in this study.

We conducted an additional sensitivity simulation to quantify the importance of the oxidant change $(\mathrm{OH}$ concentrations by a factor of 3 ) when estimating the controllable OA concentrations. In this sensitivity simulation, we excluded the emissions from combustion sources for aerosol species and SOA precursors (primary S /IVOCs, aromatics (ARO1 and ARO2), alkanes (ALK4 and ALK5), and olefins (OLE1 and OLE2)) without changing the emissions of the other gaseous species $\left(\mathrm{CO}, \mathrm{NO}_{\mathrm{x}}, \mathrm{SO}_{2}\right.$, and other VOCs). Period-averaged $\mathrm{OH}$ concentrations in this sensitivity simulation were nearly the same as those in the base case simulation (the difference 


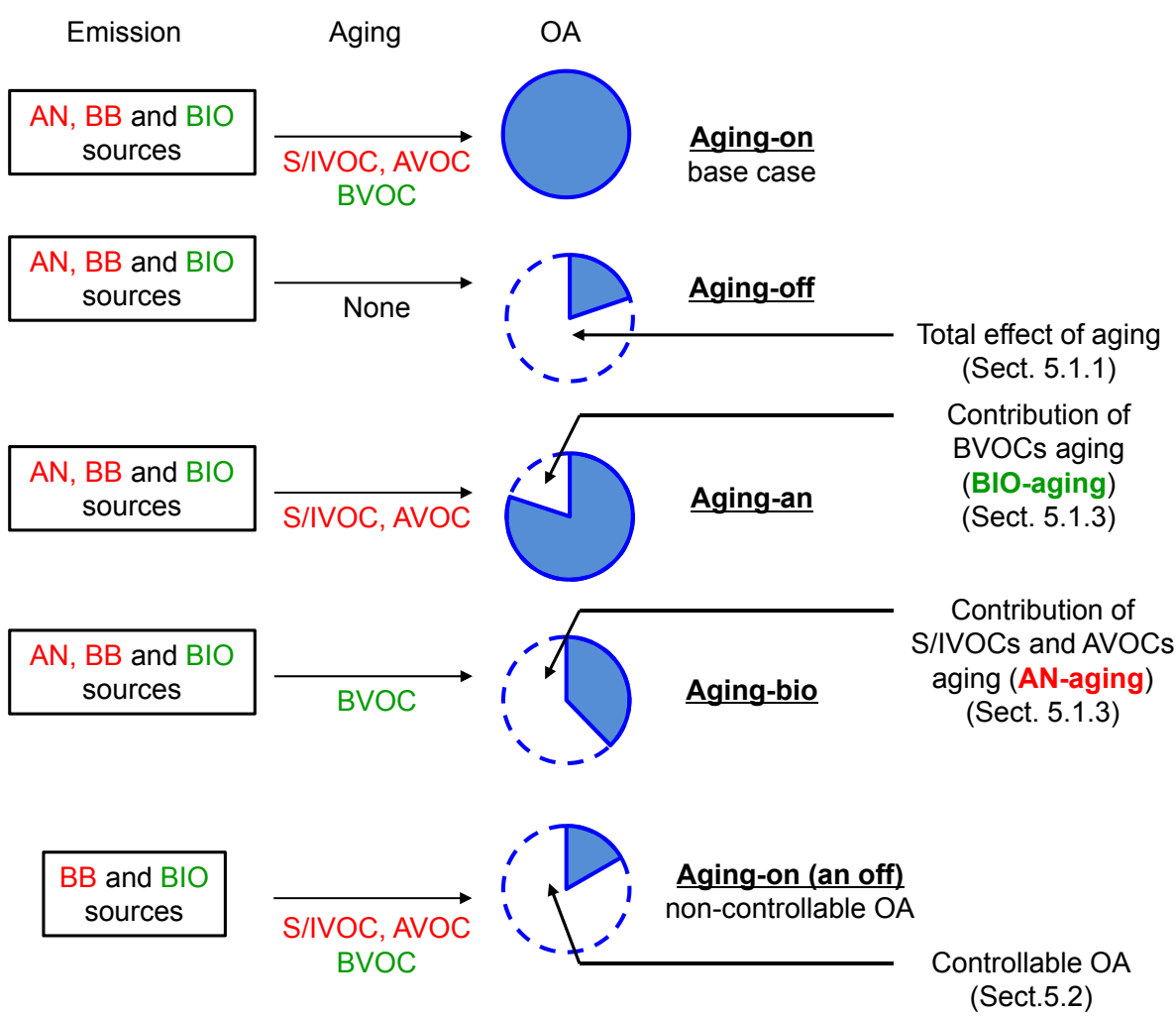

Figure 9. Diagram of sensitivity simulations conducted in Sect. 5. OA contributions estimated from individual simulations are shown. AVOC and BVOC denote anthropogenic and biogenic OVOCs, respectively.

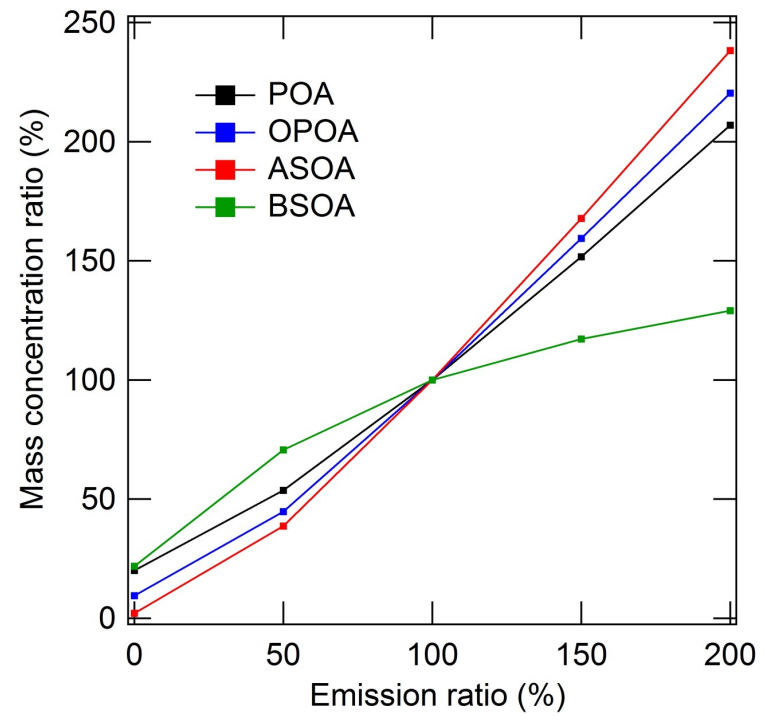

Figure 10. Sensitivity of POA, OPOA, ASOA, and BSOA mass concentrations to changes in anthropogenic emissions $\left(\mathrm{CO}, \mathrm{NO}_{\mathrm{X}}\right.$, $\mathrm{SO}_{2}$, VOCs, S/IVOCs, POA and BC) at an altitude of about $1 \mathrm{~km}$ over the outer domain. Mass concentrations and anthropogenic emissions in the sensitivity simulations are normalized by those in the base case simulation. between the two simulations is $7 \%$ for $\mathrm{OH}$ and $0.3 \%$ for $\mathrm{HO}_{2}$ over East Asia). This sensitivity simulation reduced OA concentrations by $73 \%$ and BSOA concentrations by $42 \%$ over East Asia. These results suggest that the $\mathrm{OH}$ change by $\mathrm{NO}_{\mathrm{x}}$ and VOCs has a large potential to increase controllable OA amounts over East Asia (from 73 to $87 \%$ for total OA and from 42 to $78 \%$ for BSOA).

Carlton et al. (2010) estimated that more than $50 \%$ of BSOA in the eastern United States was controllable. Global modeling studies have shown that only $31 \%$ (Tsigaridis et al., 2006) and $21 \%$ (Hoyle et al., 2009) of the simulated SOA increase from the preindustrial period to the present was formed directly from anthropogenic VOC, and that the greatest part of the remainder was BSOA enhanced by anthropogenic sources (Hoyle et al., 2011). Spracklen et al. (2011) made top-down estimates of a global SOA budget by using AMS measurements and global model simulations: these estimates suggested that $71 \%$ of SOA formed in the atmosphere was controllable. The contribution of controllable OA estimated in this study is greater than previously estimated contributions. The higher contribution of controllable OA in this study is because anthropogenic sources are dominant over East Asia and OA is enhanced considerably by aging processes of organic vapors from anthropogenic sources (Sect. 5.1.3). 
(a)

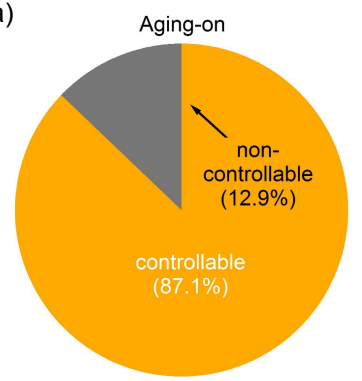

(b)

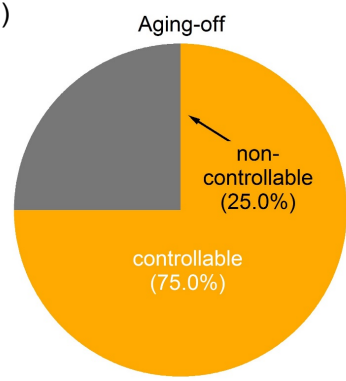

(c)

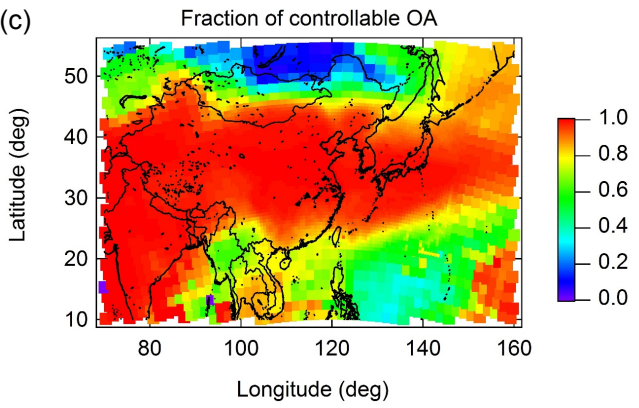

Figure 11. Period-averaged (24 March-26 April 2009) fraction of controllable and noncontrollable OA mass concentrations at an altitude of about $1 \mathrm{~km}$ over the outer domain for simulations with (a) or without (b) aging. Period-averaged (24 March-26 April 2009) fraction of controllable $\mathrm{OA}$ at an altitude of about $1 \mathrm{~km}$ over the outer domain for the simulation with aging (c).

Carlton and Turpin (2013) suggested that aerosol water produced in anthropogenic aerosols (e.g., $\mathrm{SO}_{4}$ ) would enhance biogenic SOA mass concentrations in the eastern US through aqueous-phase chemistry. This process is not considered in our model but could be an important mechanism for enhancing controllable OA concentrations in East Asia because the spatial distributions of $\mathrm{SO}_{4}$ and $\mathrm{OA}$ are generally similar over East Asia.

Our estimation of the controllable OA fraction may include large uncertainties because biomass burning emissions are still highly uncertain over East Asia (Matsui et al., 2013a). The estimation may also be highly sensitive to the simulation periods due to the large seasonal and interannual variations of biomass burning over East Asia (Matsui et al., 2013a). Since biomass burning emissions are highest during February-April over Southeast Asia and during March-May over China (Matsui et al., 2013a), a higher fraction of controllable $\mathrm{OA}$ is expected during the other seasons in terms of biomass burning emissions.

Without aging processes, the domain- and period-averaged controllable OA is $0.18 \mu \mathrm{g} \mathrm{m}^{-3}$, and the fraction of controllable OA is $75 \%$ (Fig. 11b). The fraction is lower than that in the base case simulation with aging processes. This is because the fraction of OPOA and ASOA, which are mainly formed from anthropogenic sources, is larger in the base case simulation. Both the amounts (from 0.18 to $1.12 \mu \mathrm{g} \mathrm{m}^{-3}$ ) and

the fraction (from 75 to $87 \%$ ) of controllable OA are increased by aging processes of organic vapors over East Asia.

\section{Summary and conclusions}

We simulated OA concentrations over East Asia and its outflow region by using the VBS approach. Model simulations were evaluated via comparisons with the AMS measurements in and around Tokyo (at the Komaba and Kisai sites during the IMPACT-2 campaign in summer 2003 and the IMPACT-L campaign in summer 2004) and over the outflow region in East Asia (at the Fukue and Hedo sites during the A-FORCE campaign in spring 2009).

Model simulations with aging processes of organic vapors (S / IVOCs and OVOCs) reproduced the mass concentrations, temporal variations, and formation efficiency (i.e., $\mathrm{SOA} / \mathrm{O}_{3}$ and $\mathrm{OA} / \mathrm{SO}_{4}$ ratio) of observed $\mathrm{OA}$ with reasonable accuracy: the model reproduced SOA concentrations to within $25 \%$ during the IMPACT campaign (NMB of -21 and $-13 \%$ at Komaba and Kisai, respectively), the $\mathrm{SOA} / \mathrm{O}_{3}$ ratio to within $25 \%$ at Komaba and Kisai, OA concentrations to within $15 \%$ at Fukue and within a factor of 2 at Hedo, and the $\mathrm{OA} / \mathrm{SO}_{4}$ ratio to within $30 \%$ at Fukue and Hedo. In contrast, the simulations without the aging processes did not capture these features. The model without the aging processes severely underestimated mass concentrations (by 76-88\%) and formation efficiencies of OA (by 80-90\%) at the four measurement sites. Thus, the oxidation of organic vapors is essential for realistic OA simulations over East Asia.

Concentrations of simulated POA and total SOA (OPOA + ASOA + BSOA) peaked over northern and central China and Southeast Asia, corresponding to large source regions of anthropogenic and biomass burning emissions. Concentrations of ASOA (BSOA) were high over central and northern China (Southeast Asia and southern China). Simulated OA concentrations at an altitude of $1 \mathrm{~km}$ over East Asia were highly sensitive to aging processes of organic vapors: relative to the results of simulations without aging, total OA concentrations increased from 0.24 to $1.28 \mu \mathrm{g} \mathrm{m}^{-3}$ ( $+440 \%$ ). Aging processes also changed OA chemical composition: in the simulation with the aging processes, the contributions of OPOA and ASOA were 29 and $26 \%$, respectively, of total $\mathrm{OA}$, whereas in the simulation without the aging processes, about $70 \%$ of total OA was POA.

We also examined the importance of the aging processes of organic vapors from anthropogenic (AN-aging) and biogenic sources (BIO-aging). AN-aging was very important for the enhancement of OA formation from both anthropogenic and biogenic sources. AN-aging enhanced BSOA concentrations considerably $(+45 \%)$, while the enhancement of OPOA and ASOA (SOA from anthropogenic sources) by BIO-aging was very limited (less than 4-7\%). The difference in the importance of $\mathrm{AN}$-aging and $\mathrm{BIO}$-aging is because anthropogenic sources are dominant over East Asia. These results show 
that BSOA concentrations are substantially enhanced by OA models that can simulate realistic OA concentrations from anthropogenic sources in the atmosphere, even if we do not change the treatment of BSOA formation processes in the model. Therefore, to obtain more accurate simulations of BSOA, which is considered to be dominant globally, it is important to use a realistic OA formation scheme for anthropogenic sources.

The fraction of controllable OA estimated in our simulations was $87 \%$, suggesting that most of the OA was controllable and formed anthropogenically in springtime over all of East Asia. The fractions of controllable POA, OPOA, ASOA, and BSOA were $80,91,98$, and $78 \%$, respectively, which indicated that a large portion of BSOA was formed through the influence of anthropogenic sources (the enhancement of anthropogenic VOCs, $\mathrm{NO}_{\mathrm{x}}$, and preexisting OA). These fractions were greater than the fraction of anthropogenic emissions $(70 \%$ of OA emissions and $90 \%$ of aromatics emissions over East Asia during the simulation periods). An important reason for these higher controllable fractions was higher $\mathrm{OH}$ concentration resulting in faster oxidation rates of organic vapors by considering anthropogenic sources. Both the amounts (from 0.18 to $1.12 \mu \mathrm{g} \mathrm{m}^{-3}$ ) and the fraction (from 75 to $87 \%$ ) of controllable OA were increased by including aging processes of organic vapors over East Asia.

This study is a first step to examine OA concentrations and their spatial distributions and the anthropogenic-biogenic interaction in OA formation over East and Southeast Asia and its outflow regions. Further validations of OA, precursor VOCs, and oxidant species especially over southern China and Southeast Asia, where the contribution of biogenic sources are high, are necessary to understand the behavior of $\mathrm{OA}$ and the anthropogenic-biogenic interaction over the Asian region more quantitatively.

Acknowledgements. This work was supported by the Ministry of Education, Culture, Sports, Science, and Technology and the Japan Society for the Promotion of Science (MEXT/JSPS) KAKENHI grant numbers 26740014 and 23221001 and the GRENE Arctic Climate Change Research Project. This work was also supported by the strategic international cooperative program of the Japan Science and Technology Agency, by the global environment research fund of the Ministry of the Environment, Japan (2A-1101 and 2-1403), and by the Alliance for Global Sustainability project of the University of Tokyo. J. D. Fast was supported by the US Department of Energy (DOE) Atmospheric System Research (ASR) program under contract DE-AC06-76RLO 1830 at PNNL. PNNL is operated for the US DOE by Battelle Memorial Institute. The authors thank Nobuyuki Takegawa at the Research Center for Advanced Science and Technology, University of Tokyo (now at the Department of Chemistry, Tokyo Metropolitan University), for providing the AMS observation data at the Komaba and Kisai sites during the IMPACT campaign. For a portion of the simulations, we used the supercomputer systems in the University of Tokyo and in the Japan Agency for Marine-Earth Science and Technology.

Edited by: D. Topping

\section{References}

Abdul-Razzak, H. and Ghan, S. J.: A parameterization of aerosol activation: 2. Multiple aerosol types, J. Geophys. Res., 105, 68376844, doi:10.1029/1999JD901161, 2000.

Adhikary, B., Carmichael, G. R., Kulkarni, S., Wei, C., Tang, Y., D’Allura, A., Mena-Carrasco, M., Streets, D. G., Zhang, Q., Pierce, R. B., Al-Saadi, J. A., Emmons, L. K., Pfister, G. G., Avery, M. A., Barrick, J. D., Blake, D. R., Brune, W. H., Cohen, R. C., Dibb, J. E., Fried, A., Heikes, B. G., Huey, L. G., O'Sullivan, D. W., Sachse, G. W., Shetter, R. E., Singh, H. B., Campos, T. L., Cantrell, C. A., Flocke, F. M., Dunlea, E. J., Jimenez, J. L., Weinheimer, A. J., Crounse, J. D., Wennberg, P. O., Schauer, J. J., Stone, E. A., Jaffe, D. A., and Reidmiller, D. R.: A regional scale modeling analysis of aerosol and trace gas distributions over the eastern Pacific during the INTEX-B field campaign, Atmos. Chem. Phys., 10, 2091-2115, doi:10.5194/acp-10-20912010, 2010.

Ahmadov, R., McKeen, S. A., Robinson, A. L., Bahreini, R., Middlebrook, A. M., de Gouw, J. A., Meagher, J., Hsie, E.Y., Edgerton, E., Shaw, S., and Trainer, M.: A volatility basis set model for summertime secondary organic aerosols over the eastern United States in 2006, J. Geophys. Res., 117, D06301, doi:10.1029/2011JD016831, 2012.

Athanasopoulou, E., Vogel, H., Vogel, B., Tsimpidi, A. P., Pandis, S. N., Knote, C., and Fountoukis, C.: Modeling the meteorological and chemical effects of secondary organic aerosols during an EUCAARI campaign, Atmos. Chem. Phys., 13, 625-645, doi:10.5194/acp-13-625-2013, 2013.

Bahadur, R., Habib, G., and Russell, L. M.: Climatology of PM2.5 organic carbon concentrations from a review of ground-based atmospheric measurements by evolved gas analysis, Atmos. Environ., 43, 1591-1602, 2009.

Binkowski, F. S. and Shankar, U.: The regional particulate matte model: 1. Model description and preliminary results, J. Geophys. Res., 100, 26191-26209, 1995.

Bond, T. C., Doherty, S. J., Fahey, D. W., Forster, P. M., Berntsen, T., DeAngelo, B. J., Flanner, M. G., Ghan, S., Kärcher, B., Koch, D., Kinne, S., Kondo, Y., Quinn, P. K., Sarofim, M. C., Schultz, M. G., Schulz, M., Venkataraman, C., Zhang, H., Zhang, S., Bellouin, N., Guttikunda, S. K., Hopke, P. K., Jacobson, M. Z., Kaiser, J. W., Klimont, Z., Lohmann, U., Schwarz, J. P., Shindell, D., Storelvmo, T., Warren, S. G., and Zender, C. S.: Bounding the role of black carbon in the climate system: A scientific assessment, J. Geophys. Res. Atmos., 118, 5380-5552, doi:10.1002/jgrd.50171, 2013.

Carlton, A. G. and Turpin, B. J.: Particle partitioning potential of organic compounds is highest in the Eastern US and driven by anthropogenic water, Atmos. Chem. Phys., 13, 10203-10214, doi:10.5194/acp-13-10203-2013, 2013.

Carlton, A. G., Pinder, R. W., Bhave, P. V., and Pouliot, G. A.: To what extent can biogenic SOA be controlled?, Environ. Sci. Technol., 44, 3376-3380, 2010.

Carmichael, G. R., Tang, Y., Kurata, G., Uno, I., Streets, D., Woo, J.-H., Huang, H., Yienger, J., Lefer, B., Shetter, R., Blake, D., Atlas, E., Fried, A., Apel, E., Eisele, F., Cantrell, C., Avery, M., Barrick, J., Sachse, G., Brune, W., Sandholm, S., Kondo, Y., Singh, H., Talbot, R., Bandy., A., Thorton, D., Clarke, A., and Heikes, B.: Regional-scale chemical transport modeling in support of the analysis of observations obtained 
during the TRACE-P experiment, J. Geophys. Res., 108, 8823, doi:10.1029/2002JD003117, 2003.

Carter, W. P. L.: Documentation of the SAPRC-99 Chemical Mechanism for VOC Reactivity Assessment, Report to the California Air Resources Board. College of Engineering, Center for Environmental Research and Technology, University of California at Riverside, CA. Contracts 92-329 and 95-308, available at: http://www.cert.ucr.edu/ carter/reactdat.htm (last access: 9 September 2014), 2000.

Chung, S. and Seinfeld, J. H.: Global distribution and climate forcing of carbonaceous aerosols, J. Geophys. Res., 107, 4407, doi:10.1029/2001JD001397, 2002.

de Gouw, J. and Jimenez, J. L.: Organic aerosols in the Earth's atmosphere, Environ. Sci. Technol., 43, 7614-7618, 2009.

Dentener, F., Kinne, S., Bond, T., Boucher, O., Cofala, J., Generoso, S., Ginoux, P., Gong, S., Hoelzemann, J. J., Ito, A., Marelli, L., Penner, J. E., Putaud, J.-P., Textor, C., Schulz, M., van der Werf, G. R., and Wilson, J.: Emissions of primary aerosol and precursor gases in the years 2000 and 1750 prescribed data-sets for AeroCom, Atmos. Chem. Phys., 6, 4321-4344, doi:10.5194/acp-64321-2006, 2006.

Donahue, N. M., Robinson, A. L., Stanier, C. O., and Pandis, S. N.: Coupled partitioning, dilution, and chemical aging of semivolatile organics, Environ. Sci. Technol., 40, 2635-2643, 2006

Donahue, N. M., Epstein, S. A., Pandis, S. N., and Robinson, A. L.: A two-dimensional volatility basis set: 1 . organic-aerosol mixing thermodynamics, Atmos. Chem. Phys., 11, 3303-3318, doi:10.5194/acp-11-3303-2011, 2011.

Easter, R. C., Ghan, S. J., Zhang, Y., Saylor, R. D., Chapman, E. G., Laulainen, N. S., Abdul-Razzak, H., Leung, L. R., Bian, X., and Zaveri, R. A.: MIRAGE: Model description and evaluation of aerosols and trace gases, J. Geophys. Res., 109, D20210, doi:10.1029/2004JD004571, 2004.

Ervens, B., Turpin, B. J., and Weber, R. J.: Secondary organic aerosol formation in cloud droplets and aqueous particles (aqSOA): a review of laboratory, field and model studies, Atmos. Chem. Phys., 11, 11069-11102, doi:10.5194/acp-1111069-2011, 2011

Fahey, K. M. and Pandis, S. N.: Optimizing model performance: Variable size resolution in cloud chemistry modeling, Atmos. Environ., 35, 4471-4478, 2001.

Farina, S. C., Adams, P. J., and Pandis, S. N.: Modeling global secondary organic aerosol formation and processing with the volatility basis set: Implications for anthropogenic secondary organic aerosol, J. Geophys. Res., 115, D09202, doi:10.1029/2009JD013046, 2010.

Fast, J. D., Gustafson Jr., W. I., Easter, R. C., Zaveri, R. A., Barnard, J. C., Chapman, E. G., Grell, G. A., and Peckham, S. E.: Evolution of ozone, particulates, and aerosol direct radiative forcing in the vicinity of Houston using a fully coupled meteorology-chemistry-aerosol model, J. Geophys. Res., 111, D21305, doi:10.1029/2005JD006721, 2006.

Fountoukis, C., Racherla, P. N., Denier van der Gon, H. A. C., Polymeneas, P., Charalampidis, P. E., Pilinis, C., Wiedensohler, A., Dall'Osto, M., O'Dowd, C., and Pandis, S. N.: Evaluation of a three-dimensional chemical transport model (PMCAMx) in the European domain during the EUCAARI May 2008 cam- paign, Atmos. Chem. Phys., 11, 10331-10347, doi:10.5194/acp11-10331-2011, 2011.

George, I. J., Vlasenko, A., Slowik, J. G., Broekhuizen, K., and Abbatt, J. P. D.: Heterogeneous oxidation of saturated organic aerosols by hydroxyl radicals: uptake kinetics, condensed-phase products, and particle size change, Atmos. Chem. Phys., 7, 41874201, doi:10.5194/acp-7-4187-2007, 2007.

George, I. J., Slowik, J., and Abbatt, J. P. D.: Chemical aging of ambient organic aerosol from heterogeneous reaction with hydroxyl radicals, Geophys. Res. Lett., 35, L13811, doi:10.1029/2008GL033884, 2008.

Goldstein, A. H. and Galbally, I. E.: Known and unexplored organic constituents in the Earth's atmosphere, Environ. Sci. Technol., 41, 1514-1521, 2007.

Grell, G. A., Peckham, S. E., Schmitz, R., McKeen, S. A., Frost, G., Skamarock, W. C., and Eder, B: Fully coupled "online" chemistry within the WRF model, Atmos. Environ., 39, 6957-6975, 2005.

Guenther, A., Karl, T., Harley, P., Wiedinmyer, C., Palmer, P. I., and Geron, C.: Estimates of global terrestrial isoprene emissions using MEGAN (Model of Emissions of Gases and Aerosols from Nature), Atmos. Chem. Phys., 6, 3181-3210, doi:10.5194/acp-63181-2006, 2006.

Hallquist, M., Wenger, J. C., Baltensperger, U., Rudich, Y., Simpson, D., Claeys, M., Dommen, J., Donahue, N. M., George, C., Goldstein, A. H., Hamilton, J. F., Herrmann, H., Hoffmann, T., Iinuma, Y., Jang, M., Jenkin, M. E., Jimenez, J. L., Kiendler-Scharr, A., Maenhaut, W., McFiggans, G., Mentel, Th. F., Monod, A., Prévôt, A. S. H., Seinfeld, J. H., Surratt, J. D., Szmigielski, R., and Wildt, J.: The formation, properties and impact of secondary organic aerosol: current and emerging issues, Atmos. Chem. Phys., 9, 5155-5236, doi:10.5194/acp-9-51552009, 2009.

Han, Z., Zhang, R., Wang, Q., Wang, W., Cao, J., and Xu, J.: Regional modeling of organic aerosols over China in summertime, J. Geophys. Res., 113, D11202, doi:10.1029/2007JD009436, 2008.

Heald, C. L., Jacob, D. J., Park, R. J., Russell, L. M., Huebert, B. J., Seinfeld, J. H., Liao, H., and Weber, R. J.: A large organic aerosol source in the free troposphere missing from current models, Geophys. Res. Lett., 32, L18809, doi:10.1029/2005GL023831, 2005.

Heald, C. L., Henze, D. K., Horowitz, L. W., Feddema, J., Lamarque, J.-F., Guenther, A., Hess, P. G., Vitt, F., Seinfeld, J. H., Goldstein, A. H., and Fung, I.: Predicted change in global secondary organic aerosol concentrations in response to future climate, emissions, and land use change, J. Geophys. Res., 113, D05211, doi:10.1029/2007JD009092, 2008.

Heald, C. L., Ridley, D. A., Kreidenweis, S. M., and Drury, E. E.: Satellite observations cap the atmospheric organic aerosol budget, Geophys. Res. Lett., 37, L24808, doi:10.1029/2010GL045095, 2010.

Heald, C. L., Coe, H., Jimenez, J. L., Weber, R. J., Bahreini, R., Middlebrook, A. M., Russell, L. M., Jolleys, M., Fu, T.-M., Allan, J. D., Bower, K. N., Capes, G., Crosier, J., Morgan, W. T., Robinson, N. H., Williams, P. I., Cubison, M. J., DeCarlo, P. F., and Dunlea, E. J.: Exploring the vertical profile of atmospheric organic aerosol: comparing 17 aircraft field campaigns with a global model, Atmos. Chem. Phys., 11, 12673-12696, doi:10.5194/acp-11-12673-2011, 2011. 
Herndon, S. C., Onasch, T. B., Wood, E. C., Kroll, J. H., Canagaratna, M. R., Jayne, J. T., Zavala, M. A., Knighton, W. B., Mazzoleni, C., Dubey, M. K., Ulbrich, I. M., Jimenez, J. L., Seila, R., de Gouw, J. A., de Foy, B., Fast, J., Molina, L. T., Kolb, C. E., and Worsnop, D. R.: Correlation of secondary organic aerosol with odd oxygen in Mexico City, Geophys. Res. Lett., 35, L15804, doi:10.1029/2008GL034058, 2008.

Hodzic, A., Jimenez, J. L., Madronich, S., Canagaratna, M. R., DeCarlo, P. F., Kleinman, L., and Fast, J.: Modeling organic aerosols in a megacity: potential contribution of semi-volatile and intermediate volatility primary organic compounds to secondary organic aerosol formation, Atmos. Chem. Phys., 10, 5491-5514, doi:10.5194/acp-10-5491-2010, 2010.

Hoyle, C. R., Myhre, G., Berntsen, T. K., and Isaksen, I. S. A.: Anthropogenic influence on SOA and the resulting radiative forcing, Atmos. Chem. Phys., 9, 2715-2728, doi:10.5194/acp-9-27152009, 2009.

Hoyle, C. R., Boy, M., Donahue, N. M., Fry, J. L., Glasius, M., Guenther, A., Hallar, A. G., Huff Hartz, K., Petters, M. D., Petäjä, T., Rosenoern, T., and Sullivan, A. P.: A review of the anthropogenic influence on biogenic secondary organic aerosol, Atmos. Chem. Phys., 11, 321-343, doi:10.5194/acp-11-321-2011, 2011.

Huang, H., Ho, K. F., Lee, S. C., Tsang, P. K., Ho, S. S. H., Zou, C. W., Zou, S. C., Cao, J. J., and Xu, H. M.: Characteristics of carbonaceous aerosol in $\mathrm{PM}_{2.5}$ : Pearl Delta River Region, China, Atmos. Res., 104-105, 227-236, 2012.

Iinuma, Y., Böge, O., Gnauk, T., and Herrmann, H.: Aerosolchamber study of the $\alpha$-pinene $/ \mathrm{O}_{3}$ reaction: Influence of particle acidity on aerosol yields and products, Atmos. Environ., 38, 761-773, 2004.

Jacobson, M. Z., Turco, R. P., Jensen, E. J., and Toon, O. B.: Modeling coagulation among particles of different composition and size, Atmos. Environ., 28, 1327-1338, 1994.

Jathar, S. H., Farina, S. C., Robinson, A. L., and Adams, P. J.: The influence of semi-volatile and reactive primary emissions on the abundance and properties of global organic aerosol, Atmos. Chem. Phys., 11, 7727-7746, doi:10.5194/acp-11-7727-2011, 2011.

Jiang, F., Liu, Q. Huang, X. X., Wang, T. J., Zhuang, B. L., and Xie, M.: Regional modeling of secondary organic aerosol over China using WRF/Chem, J. Aerosol Sci., 43, 57-73, 2012.

Jimenez, J. L., Canagaratna, M. R., Donahue, N. M., Prevot, A. S. H., Zhang, Q., Kroll, J. H., DeCarlo, P. F., Allan, J. D., Coe, H., Ng, N. L., Aiken, A. C., Docherty, K. S., Ulbrich, I. M., Grieshop, A. P., Robinson, A. L., Duplissy, J., Smith, J. D., Wilson, K. R., Lanz, V. A., Hueglin, C., Sun, Y. L., Tian, J., Laaksonen, A., Raatikainen, T., Rautiainen, J., Vaattovaara, P., Ehn, M., Kulmala, M., Tomlinson, J. M., Collins, D. R., Cubison, M. J., Dunlea, E. J., Huffman, J. A., Onasch, T. B., Alfarra, M. R., Williams, P. I., Bower, K., Kondo, Y., Schneider, J., Drewnick, F., Borrmann, S., Weimer, S., Demerjian, K., Salcedo, D., Cottrell, L., Griffin, R., Takami, A., Miyoshi, T., Hatakeyama, S., Shimono, A., Sun, J. Y., Zhang, Y. M., Dzepina, K., Kimmel, J. R., Sueper, D., Jayne, J. T., Herndon, S. C., Trimborn, A. M., Williams, L. R., Wood, E. C., Middlebrook, A. M., Kolb, C. E., Baltensperger, U., and Worsnop, D. R.: Evolution of organic aerosols in the atmosphere, Science, 326, 1525-1529, 2009.

Kalberer, M., Paulsen, D., Sax, M., Steinbacher, M., Dommen, J., Prevot, A. S. H., Fisseha, R., Weingartner, E., Frankevich, V.,
Zanobi, R., and Baltensperger, U.: Identification of polymers as major components of atmospheric organic aerosols, Science, 303, 1659-1662, 2004.

Kanakidou, M., Seinfeld, J. H., Pandis, S. N., Barnes, I., Dentener, F. J., Facchini, M. C., Van Dingenen, R., Ervens, B., Nenes, A., Nielsen, C. J., Swietlicki, E., Putaud, J. P., Balkanski, Y., Fuzzi, S., Horth, J., Moortgat, G. K., Winterhalter, R., Myhre, C. E. L., Tsigaridis, K., Vignati, E., Stephanou, E. G., and Wilson, J.: Organic aerosol and global climate modelling: a review, Atmos. Chem. Phys., 5, 1053-1123, doi:10.5194/acp-5-1053-2005, 2005.

Kanaya, Y., Cao, R., Akimoto, H., Fukuda, M., Komazaki, Y., Yokouchi, Y., Koike, M., Tanimoto, H., Takegawa, N., and Kondo, Y.: Urban photochemistry in central Tokyo: 1. Observed and modeled $\mathrm{OH}$ and $\mathrm{HO}_{2}$ radical concentrations during the winter and summer of 2004, J. Geophys. Res., 112, D21312, doi:10.1029/2007JD008670, 2007.

Kannari, A., Baba, T., Ueda, H., Tonooka, Y., and Matsuda, K.: Development of a grid database on atmospheric pollutants emissions in Japan, J. Jpn. Soc. Atmos. Environ., 39, 257-271, 2004 (in Japanese).

Kondo, Y., Komazaki, Y., Miyazaki, Y., Moteki, N., Takegawa, N., Kodama, D., Deguchi, S., Nogami, M., Fukuda, M., Miyakawa, T., Morino, Y., Koike, M., Sakurai, H., and Ehara, K.: Temporal variations of elemental carbon in Tokyo, J. Geophys. Res., 111, D12205, doi:10.1029/2005JD006257, 2006.

Kondo, Y., Miyazaki, Y., Takegawa, N., Miyakawa, T., Weber, R. J., Jimenez, J. L., Zhang, Q., and Worsnop, D. R.: Oxygenated and water-soluble organic aerosols in Tokyo, J. Geophys. Res., 112, D01203, doi:10.1029/2006JD007056, 2007.

Kondo, Y. Morino, Y., Fukuda, M., Kanaya, Y., Miyazaki, Y., Takegawa, N., Tanimoto, H., McKenzie, R., Johnston, P., Blake, D. R., Murayama, T., and Koike, M: Formation and transport of oxidized reactive nitrogen, ozone, and secondary organic aerosol in Tokyo, J. Geophys. Res., 113, D21310, doi:10.1029/2008JD010134, 2008.

Kondo, Y., Takegawa, N., Matsui, H., Miyakawa, T., Koike, M., Miyazaki, Y., Kanaya, Y., Mochida, M., Kuwata, M., Morino, Y., and Shiraiwa, M.: Formation and transport of aerosols in Tokyo in relation to their physical and chemical properties: A review, J. Meteorol. Soc. Jpn., 88, 597-624, 2010.

Kondo, Y., Oshima, N., Kajino, M., Mikami, R., Moteki, N., Takegawa, N., Verma, R. L., Kajii, Y., Kato, S., and Takami, A.: Emissions of black carbon in East Asia estimated from observations at a remote site in the East China Sea, J. Geophys. Res., 116, D16201, doi:10.1029/2011JD015637, 2011.

Koo, B., Ansari, A. S., and Pandis, S. N.: Integrated approaches to modeling the organic and inorganic atmospheric aerosol components, Atmos. Environ., 37, 4757-4768, 2003.

Kroll, J. H., Smith, J. D., Che, D. L., Kessler, S. H., Worsnop, D. R., and Wilson, K. R.: Measurement of fragmentation and functionalization pathways in the heterogeneous oxidation of oxidized organic aerosol, Phys. Chem. Chem. Phys. 11, 8005-8014, 2009.

Lane, T. E., Donahue, N. M., and Pandis, S. N.: Effect of $\mathrm{NO}_{\mathrm{x}}$ on secondary organic aerosol concentrations, Environ. Sci. Technol., 42, 6022-6027, 2008a.

Lane, T. E., Donahue, N. M., and Pandis, S. N.: Simulating secondary organic aerosol formation using the volatility basis-set 
approach in a chemical transport model, Atmos. Environ., 42, 7439-7451, 2008b.

Levine, S. Z. and Schwartz, S. E.: In-cloud and below-cloud scavenging of nitric acid vapor, Atmos. Environ., 16, 1725-1734, 1982.

Li, N., Fu, T.-M., Cao, J., Lee, S., Huang, X.-F., He, L.-Y., Ho, K.-F., Fu, J. S., and Lam, Y.-F.: Sources of secondary organic aerosols in the Pearl River Delta region in fall: Contributions from the aqueous reactive uptake of dicarbonyls, Atmos. Environ., 76, 200-207, 2013.

Liu, J., Horowitz, L. W., Fan, S., Carlton, A. G., and Levy II, H.: Global in-cloud production of secondary organic aerosols: Implementation of a detailed chemical mechanism in the GFDL atmospheric model AM3, J. Geophys. Res., 117, D15303, doi:10.1029/2012JD017838, 2012.

Mahmud, A. and Barsanti, K.: Improving the representation of secondary organic aerosol (SOA) in the MOZART-4 global chemical transport model, Geosci. Model Dev., 6, 961-980, doi:10.5194/gmd-6-961-2013, 2013.

Matsui, H., Koike, M. Takegawa, N. Kondo, Y., Griffin, R. J., Miyazaki, Y., Yokouchi, Y., and Ohara, T.: Secondary organic aerosol formation in urban air: Temporal variations and possible contributions from unidentified hydrocarbons, J. Geophys. Res., 114, D04201, doi:10.1029/2008JD010164, 2009a.

Matsui, H., Koike, M., Kondo, Y., Takegawa, N., Kita, K., Miyazaki, Y., Hu, M., Chang, S.-Y., Blake, D. R., Fast, J. D., Zaveri, R. A., Streets, D. G., Zhang, Q., and Zhu, T: Spatial and temporal variations of aerosols around Beijing in summer 2006: Model evaluation and source apportionment, J. Geophys. Res., 114, D00G13, doi:10.1029/2008JD010906, 2009b.

Matsui, H., Koike, M., Kondo, Y., Takegawa, N., Fast, J. D., Pöschl, U., Garland, R. M., Andreae, M. O., Wiedensohler, A., Sugimoto, N., and Zhu, T.: Spatial and temporal variations of aerosols around Beijing in summer 2006: 2. Local and column aerosol optical properties, J. Geophys. Res., 115, D22207, doi:10.1029/2010JD013895, 2010.

Matsui, H., Kondo, Y., Moteki, N., Takegawa, N., Sahu, L. K., Zhao, Y., Fuelberg, H. E., Sessions, W. R., Diskin, G., Blake, D. R., Wisthaler, A., and Koike, M.: Seasonal variation of the transport of black carbon aerosol from the Asian continent to the Arctic during the ARCTAS aircraft campaign, J. Geophys. Res., 116, D05202, doi:10.1029/2010JD015067, 2011a.

Matsui, H., Kondo, Y., Moteki, N., Takegawa, N., Sahu, L. K., Koike, M., Zhao, Y., Fuelberg, H. E., Sessions, W. R., Diskin, G., Anderson, B. E., Blake, D. R., Wisthaler, A., Cubison, M. J., and Jimenez, J. L.: Accumulation-mode aerosol number concentrations in the Arctic during the ARCTAS aircraft campaign: Long-range transport of polluted and clean air from the Asian continent, J. Geophys. Res., 116, D20217, doi:10.1029/2011JD016189, 2011b.

Matsui, H., Koike, M., Kondo, Y., Takegawa, N., Wiedensohler, A., Fast, J. D., and Zaveri, R. A.: Impact of new particle formation on the concentrations of aerosols and cloud condensation nuclei around Beijing, J. Geophys. Res., 116, D19208, doi:10.1029/2011JD016025, 2011c.

Matsui, H., Koike, M., Kondo, Y., Oshima, N., Moteki, N., Kanaya, Y., Takami, A., and Irwin, M.: Seasonal variations of Asian black carbon outflow to the Pacific: Contribution from anthropogenic sources in China and biomass burning sources in Siberia and Southeast Asia, J. Geophys. Res. Atmos., 118, 9948-9967, doi:10.1002/jgrd.50702, 2013a.

Matsui, H., Koike, M., Kondo, Y., Moteki, N., Fast, J. D., and Zaveri, R. A.: Development and validation of a black carbon mixing state resolved three-dimensional model: Aging processes and radiative impact, J. Geophys. Res. Atmos., 118, 2304-2326, doi:10.1029/2012JD018446, 2013b.

Matsui, H., Koike, M., Takegawa, N., Kondo, Y., Takami, A., Takamura, T., Yoon, S., Kim, S.-W., Lim, H.-C., and Fast, J. D.: Spatial and temporal variations of new particle formation in East Asia using an NPF-explicit WRF-chem model: North-south contrast in new particle formation frequency, J. Geophys. Res. Atmos., 118, 11647-11663, doi:10.1002/jgrd.50821, 2013c.

McKeen, S., Chung, S. H., Wilczak, J., Grell, G., Djalalova, I., Peckham, S., Gong, W., Bouchet, V., Moffet, R., Tang, Y., Carmichael, G. R., Mathur, R., and Yu, S.: Evaluation of several $\mathrm{PM}_{2.5}$ forecast models using data collected during the ICARTT/NEAQS 2004 field study, J. Geophys. Res., 112, D10S20, doi:10.1029/2006JD007608, 2007.

Murphy, B. N., Donahue, N. M., Fountoukis, C., and Pandis, S. N.: Simulating the oxygen content of ambient organic aerosol with the 2D volatility basis set, Atmos. Chem. Phys., 11, 7859-7873, doi:10.5194/acp-11-7859-2011, 2011.

Murphy, B. N., Donahue, N. M., Fountoukis, C., Dall'Osto, M., O'Dowd, C., Kiendler-Scharr, A., and Pandis, S. N.: Functionalization and fragmentation during ambient organic aerosol aging: application of the 2-D volatility basis set to field studies, Atmos. Chem. Phys., 12, 10797-10816, doi:10.5194/acp-1210797-2012, 2012.

Odum, J. R., Hoffmann, T., Bowman, F., Collins, D., Flagan, R. C., and Seinfeld, J. H.: Gas/particle partitioning and secondary organic aerosol yields, Environ. Sci. Technol., 30, 2580-2585, 1996.

Odum, J. R., Jungkamp, T. P. W., Griffin, R. J., Flagan, R. C., and Seinfeld, J. H.: The atmospheric aerosol-forming potential of whole gasoline vapor, Science, 276, 96-99, 1997.

Oshima, N., Kondo, Y., Moteki, N., Takegawa, N., Koike, M., Kita. K., Matsui, H., Kajino, M., Nakamura, H., Jung, J. S., and Kim, Y. J.: Wet removal of black carbon in Asian outflow: Aerosol Radiative Forcing in East Asia (A-FORCE) aircraft campaign, J. Geophys. Res., 117, D03204, doi:10.1029/2011JD016552, 2012.

Oshima., N., Koike, M., Kondo, Y., Nakamura, H., Moteki, N., Matsui, H., Takegawa, N., and Kita, K.: Vertical transport mechanisms of black carbon over East Asia in spring during the A-FORCE aircraft campaign, J. Geophys. Res.-Atmos., 118, 13175-13198, doi:10.1002/2013JD020262, 2013.

Pye, H. O. T. and Seinfeld, J. H.: A global perspective on aerosol from low-volatility organic compounds, Atmos. Chem. Phys., 10, 4377-4401, doi:10.5194/acp-10-4377-2010, 2010.

Ramanathan, V., Crutzen, P. J., Kiehl, J. T., and Rosenfeld, D.: Aerosols, climate, and the hydrological cycle, Science, 294, 2119-2124, 2001.

Robinson, A. L., Donahue, N. M., Shrivastava, M. K., Weitkamp, E. A., Sage, A. M., Grieshop, A. P., Lane, T. E., Pierce, J. R., and Pandis, S. N.: Rethinking organic aerosols: Semivolatile emissions and photochemical aging, Science, 315, 1259-1262, 2007.

Sahu, L. K., Kondo, Y., Miyazaki, Y., Pongkiatkul, P., and Kim Oanh, N. T.: Seasonal and diurnal variations of black carbon 
and organic carbon aerosols in Bangkok, J. Geophys. Res., 116, D15302, doi:10.1029/2010JD015563, 2011.

Schell, B., Ackermann, I. J., Hass, H., Binkowski, F. S., and Ebel, A.: Modeling the formation of secondary organic aerosol within a comprehensive air quality model system, J. Geophys. Res., 106, 28275-28293, doi:10.1029/2001JD000384, 2001.

Shirai, T., Yokouchi, Y., Blake, D. R., Kita, K., Izumi, K., Koike, M., Komazaki, Y., Miyazaki, Y., Fukuda, M., and Kondo, Y.: Seasonal variations of atmospheric C2-C7 nonmethane hydrocarbons in Tokyo, J. Geophys. Res., 112, D24305, doi:10.1029/2006JD008163, 2007.

Shrivastava, M., Fast, J., Easter, R., Gustafson Jr., W. I., Zaveri, R. A., Jimenez, J. L., Saide, P., and Hodzic, A.: Modeling organic aerosols in a megacity: comparison of simple and complex representations of the volatility basis set approach, Atmos. Chem. Phys., 11, 6639-6662, doi:10.5194/acp-11-6639-2011, 2011.

Shrivastava, M., Zelenyuk, A., Imre, D., Easter, R., Beranek, J., Zaveri, R. A., and Fast, J.: Implications of low volatility SOA and gas-phase fragmentation reactions on SOA loadings and their spatial and temporal evolution in the atmosphere, J. Geophys. Res. Atmos., 118, 3328-3342, doi:10.1002/jgrd.50160, 2013.

Skamarock, W. C., Klemp, J. B., Dudhia, J., Gill, D. O., Barker, D. M., Wang, W., and Powers, J. G.: A description of the advanced research WRF version 3, NCAR Tech. Note, NCAR/TN475+STR, Natl. Cent. Atmos. Res., Boulder, Colo, 2008.

Spracklen, D. V., Jimenez, J. L., Carslaw, K. S., Worsnop, D. R., Evans, M. J., Mann, G. W., Zhang, Q., Canagaratna, M. R., Allan, J., Coe, H., McFiggans, G., Rap, A., and Forster, P.: Aerosol mass spectrometer constraint on the global secondary organic aerosol budget, Atmos. Chem. Phys., 11, 12109-12136, doi:10.5194/acp-11-12109-2011, 2011.

Streets, D. G., Bond, T. C., Carmichael, G. R., Fernandes, S. D., Fu, Q., He, D., Klimont, Z., Nelson, S. M., Tsai, N. Y., Wang, M. Q., Woo, J.-H., and Yarber, K. F.: An inventory of gaseous and primary aerosol emissions in Asia in the year 2000, J. Geophys. Res., 108, 8809, doi:10.1029/2002JD003093, 2003.

Takami, A., Miyoshi, T., Shimono, A., and Hatakeyama, S.: Chemical composition of fine aerosol measured by AMS at Fukue Island, Japan, during APEX period, Atmos. Environ., 39, 49134924, 2005.

Takami, A., Miyoshi, T., Shimono, A., Kaneyasu, N., Kato, S., Kajii, Y., and Hatakeyama, S.: Transport of anthropogenic aerosols from Asia and subsequent chemical transformation, J. Geophys. Res., 112, D22S31, doi:10.1029/2006JD008120, 2007.

Takegawa, N., Miyazaki, Y., Kondo, Y., Komazaki, Y., Miyakawa, T., Jimenez, J. L., Jayne, J. T., Worsnop, D. R., Allan, J., and Weber, R. J.: Characterization of an Aerodyne aerosol mass spectrometer (AMS): Intercomparison with other aerosol instruments, Aerosol Sci. Tech., 39, 760-770, 2005.

Takegawa, N., T. Miyakawa, Kondo, Y., Blake, D. R., Kanaya, Y., Koike, M., Fukuda, M., Komazaki, Y., Miyazaki, Y., Shimono, A., and Takeuchi, T.: Evolution of submicron organic aerosol in polluted air exported from Tokyo, Geophys. Res. Lett., 33, L15814, doi:10.1029/2006GL025815, 2006a.

Takegawa, N., Miyakawa, T., Kondo, Y., Jimenez, J. L., Zhang, Q., Worsnop, D. R., and Fukuda, M.: Seasonal and diurnal variations of submicron organic aerosols in Tokyo observed using the Aerodyne aerosol mass spectrometer, J. Geophys. Res., 111, D11206, doi:10.1029/2005JD006515, 2006b.
Tao, J., Shen, Z. Zhu, C., Yue, J., Cao, J., Liu, S., Zhu, L., and Zhang, R.: Seasonal variations and chemical characteristics of sub-micrometer particles $\left(\mathrm{PM}_{1}\right)$ in Guangzhou, China, Atmos. Res., 118, 222-231, 2012.

Tsigaridis, K. and Kanakidou, M.: Global modelling of secondary organic aerosol in the troposphere: a sensitivity analysis, Atmos. Chem. Phys., 3, 1849-1869, doi:10.5194/acp-3-1849-2003, 2003.

Tsigaridis, K. and Kanakidou, M.: Secondary organic aerosol importance in the future atmosphere, Atmos. Environ., 41, 46824692, 2007.

Tsigaridis, K., Krol, M., Dentener, F. J., Balkanski, Y., Lathière, J., Metzger, S., Hauglustaine, D. A., and Kanakidou, M.: Change in global aerosol composition since preindustrial times, Atmos. Chem. Phys., 6, 5143-5162, doi:10.5194/acp-6-5143-2006, 2006.

Tsimpidi, A. P., Karydis, V. A., Zavala, M., Lei, W., Molina, L., Ulbrich, I. M., Jimenez, J. L., and Pandis, S. N.: Evaluation of the volatility basis-set approach for the simulation of organic aerosol formation in the Mexico City metropolitan area, Atmos. Chem. Phys., 10, 525-546, doi:10.5194/acp-10-525-2010, 2010.

Tsimpidi, A. P., Karydis, V. A., Zavala, M., Lei, W., Bei, N., Molina, L., and Pandis, S. N.: Sources and production of organic aerosol in Mexico City: insights from the combination of a chemical transport model (PMCAMx-2008) and measurements during MILAGRO, Atmos. Chem. Phys., 11, 5153-5168, doi:10.5194/acp11-5153-2011, 2011.

Turpin, B. J. and Lim, H. J.: Species contributions to $\mathrm{PM}_{2.5}$ mass concentrations: Revisiting common assumptions for estimating organic mass, Aerosol Sci. Tech., 35, 602-610, 2001.

Utembe, S. R., Cooke, M. C., Archibald, A. T., Shallcross, D. E., Derwent, R. G., and Jenkin, M. E.: Simulating secondary organic aerosol in a 3-D Lagrangian chemistry transport model using the reduced Common Representative Intermediates mechanism (CRI v2-R5), Atmos. Environ., 45, 1604-1614, 2011.

van der Werf, G. R., Randerson, J. T., Giglio, L., Collatz, G. J., Mu, M., Kasibhatla, P. S., Morton, D. C., DeFries, R. S., Jin, Y., and van Leeuwen, T. T.: Global fire emissions and the contribution of deforestation, savanna, forest, agricultural, and peat fires (19972009), Atmos. Chem. Phys., 10, 11707-11735, doi:10.5194/acp10-11707-2010, 2010.

Wesely, M. L.: Parameterization of surface resistances to gaseous dry deposition in regional-scale numerical models, Atmos. Environ, 23, 1293-1304, 1989.

Wexler, A. S., Lurmann, F. W., and Seinfeld, J. H.: Modelling urban and regional aerosols. Part I: Model development, Atmos. Environ., 28, 531-546, 1994.

Xiao, R., Takegawa, N., Zheng, M., Kondo, Y., Miyazaki, Y., Miyakawa, T., Hu, M., Shao, M., Zeng, L., Gong, Y., Lu, K., Deng, Z., Zhao, Y., and Zhang, Y. H.: Characterization and source apportionment of submicron aerosol with aerosol mass spectrometer during the PRIDE-PRD 2006 campaign, Atmos. Chem. Phys., 11, 6911-6929, doi:10.5194/acp-11-6911-2011, 2011.

Zaveri, R. A. and Peters, L. K.: A new lumped structure photochemical mechanism for large-scale applications, J. Geophys. Res., 104, 30387-30415, doi:10.1029/1999JD900876, 1999.

Zaveri, R. A., Easter, R. C., and Wexler, A. S.: A new method for multicomponent activity coefficients of electrolytes in 
aqueous atmospheric aerosols, J. Geophys. Res., 110, D02201, doi:10.1029/2004JD004681, 2005a.

Zaveri, R. A., Easter, R. C., and Peters, L. K.: A computationally efficient Multicomponent Equilibrium Solver for Aerosols (MESA), J. Geophys. Res., 110, D24203, doi:10.1029/2004JD005618, 2005b.

Zaveri, R. A., Easter, R. C., Fast, J. D., and Peters, L. K.: Model for Simulating Aerosol Interactions and Chemistry (MOSAIC), J. Geophys. Res., 113, D13204, doi:10.1029/2007JD008782, 2008.

Zhang, Q., Alfarra, M. R., Worsnop, D. R., Allan, J. D., Coe, H., Canagaratna, M. R., and Jimenez, J. L.: Deconvolution and quantification of hydrocarbon-like and oxygenated organic aerosols based on aerosol mass spectrometry, Environ. Sci. Technol., 39, 4938-4952, 2005.
Zhang, Q., Jimenez, J. L., Canagaratna, M. R., Allan, J. D., Coe, H., Ulbrich, I., Alfarra, M. R., Takami, A., Middlebrook, A. M., Sun, Y. L., Dzepina, K., Dunlea, E., Docherty, K., DeCarlo, P. F., Salcedo, D., Onasch, T., Jayne, J. T., Miyoshi, T., Shimono, A., Hatakeyama, S., Takegawa, N., Kondo, Y., Schneider, J., Drewnick, F., Borrmann, S., Weimer, S., Demerjian, K., Williams, P., Bower, K., Bahreini, R., Cottrell, L., Griffin, R. J., Rautiainen, J., Sun, J. Y., and Zhang, Y., M.: Ubiquity and dominance of oxygenated species in organic aerosols in anthropogenically influenced Northern Hemisphere midlatitudes, Geophys. Res. Lett., 34, L13801, doi:10.1029/2007GL029979, 2007.

Zhang, Y., Pun, B., Vijayaraghavan, K., Wu, S.-Y., Seigneur, C., Pandis, S. N., Jacobson, M. Z., Nenes, A., and Seinfeld, J. H.: Development and application of the Model of Aerosol Dynamics, Reaction, Ionization, and Dissolution (MADRID), J. Geophys. Res., 109, D01202, doi:10.1029/2003JD003501, 2004. 